\title{
Fracture surface characterization of laser welding processed Ti alloy to stainless steel joints
}

\author{
Seyed Reza Elmi Hosseini ${ }^{1} \cdot$ Kai Feng $^{1} \cdot$ Pulin Nie $^{1} \cdot \mathrm{Ke} \mathrm{Zhang}^{1} \cdot$ Jian Huang ${ }^{1,2} \cdot$ Yuan Chen ${ }^{1} \cdot$ Da Shu $^{1} \cdot$ Zhuguo Li $^{1,2,3}$. \\ Baochao $\mathrm{Guo}^{4}$. Song Xue ${ }^{4}$
}

Received: 16 November 2017 / Accepted: 16 March 2018 / Published online: 23 April 2018

(C) The Author(s) 2018

\begin{abstract}
The laser welding of Ti6Al4V alloy to 304 stainless steel using a 1-mm-thick $\mathrm{Cu}$ interlayer was developed by changing the laser power. The fracture characteristics of joints were analyzed by SEM, EDS, and XRD. The fracture examinations indicated that both the joint strength and the fracture occurrence location in the joints depend on the laser power settings. The optimal value for the maximized tensile strength of the joints, up to $300 \mathrm{MPa}$, was obtained at a power of $4 \mathrm{~kW}$. Increasing the laser power by $4 \mathrm{~kW}$ increased the tensile strength; it decreased as the laser power exceeded $4 \mathrm{~kW}$. In the 4-kW samples, the fracture characterization indicated that the higher remaining $\mathrm{Cu}$ deposited on the $\mathrm{Ti}$ sheet that caused the fracture path tended to make the fracture propagate toward the $\mathrm{Cu}$ interlayer. The fractography investigations illustrated that the fracture surface of a $4-\mathrm{kW}$ joint had a greater rough area than that of either the 3- or the 6-kW joints. The XRD results demonstrated that the most of solid solution phases, such as $\alpha \mathrm{Ti},(\mathrm{V})$, and $(\mathrm{Ni})$ coexisting with various types of Al-intermetallics could occur on the fracture surface of a 4-kW weldment.
\end{abstract}

Keywords Titanium alloy $\cdot$ AISI 304 stainless steel $\cdot$ Laser welding $\cdot$ Intermetallic $\cdot$ Mechanical strength $\cdot$ Fracture path

\section{Introduction}

High-strength joints between titanium (Ti) alloys and stainless steel (SS) provide many technological advantages in chemical, petrochemical, cryogenic, microelectronics, medical, nuclear, thermal power station, aerospace, spacecraft, aeronautics, and astronautics industries. They do so by providing a reliable and low-cost way of tailoring the location of materials

Recommended for publication by Commission IX - Behaviour of Metals Subjected to Welding

Zhuguo Li

lizg@sjtu.edu.cn

1 Shanghai Key Laboratory of Materials Laser Processing and Modification, School of Materials Science and Engineering, Shanghai Jiao Tong University, Shanghai 200240, China

2 Collaborative Innovation Center for Advanced Ship and Deep-Sea Exploration, Shanghai 200240, China

3 Shanghai Innovation Institute for Materials, Shanghai 200444, China

4 Shanghai No. 1 Machine Tool Works Co., Ltd., Shanghai 201308, China according to design and performance, while at the same time offering mass-saving advantages by using titanium alloys [1-3]. In order to achieve compatibility between material costs and function, Ti alloys are used for applications requiring chemical properties such as corrosion resistance, stability in aqueous media, and high specific strength [4]. Austenitic stainless steels are used for applications that require greater levels of workability [5].

The direct welding of Ti alloys and SS suffers from two major challenges. The first challenge is the brittle intermetallic compounds (IMCs) formed at the joint, such as brittle $\mathrm{TiFe}_{2}$ and $\mathrm{TiCr}_{2}$ phases. This is due to the limited miscibility of iron and titanium. According to the Fe-Ti phase diagram, the solubility of $\mathrm{Fe}$ in $\mathrm{Ti}$ is very low ( $0.1 \%$ at room temperature). Beyond this, the brittle intermetallic phases FeTi and then $\mathrm{Fe}_{2} \mathrm{Ti}$ (600 and $1000 \mathrm{HV}$, respectively) begin to form. The second challenge is the formation of cracks and residual stresses, caused by the large differences in thermal expansion and heat conductivity coefficients between Ti alloy and SS. The thermal expansion coefficients of Ti6Al4V and $304 \mathrm{SS}$ are $8.7 \times 10^{-6} \mathrm{~K}^{-1}$ and $16 \times 10^{-6} \mathrm{~K}^{-1}$, respectively. Also, the heat conductivity coefficients of Ti6Al4V alloy and $304 \mathrm{SS}$ are 6.7 and $14.6 \mathrm{~W} / \mathrm{m} . \mathrm{K}$, respectively. The specimens fracture 
spontaneously when sufficient amounts of IMCs have formed. Therefore, preventing the formation of brittle IMCs is the key to achieving reliable joining of Ti alloys and SS [1, 3, 6-10].

The mechanical stability of the weld between Ti alloys and SS can be increased by the insertion of intermediate metal foils that change the character of the interaction in the melted zone (MZ) and lead to the formation of phases other than TiFe-rich intermetallic phases $[11,12]$. The most popular of these "bond layer" materials are $\mathrm{Ni}, \mathrm{Cu}, \mathrm{Ag}, \mathrm{Al}, \mathrm{Mg}$, as well as some other more complex alloys which form IMCs with Ti. These act by prohibiting the atomic diffusion between $\mathrm{Ti}$ and $\mathrm{Fe}, \mathrm{Cr}$, or Ni [13].

Another group of candidates for joining stainless steels to titanium alloys are the metals that do not form intermetallic phases with Ti, such as $\mathrm{V}, \mathrm{Zr}, \mathrm{Nb}, \mathrm{Mo}$, Ta, and Hf. The most popular of these is pure $\mathrm{V}$, which forms continuous solid solutions with $\mathrm{Ti}$ and has a close fusion temperature $\left(1670{ }^{\circ} \mathrm{C}\right.$ for Ti and $1914^{\circ} \mathrm{C}$ for V) [1]. It is well known that titanium does not form intermetallic phases with pure $\mathrm{Zr}$, Nb, Mo, Ta, V, or $\mathrm{Hf}$, which could be examined as potential interlayers.

The high cost of all of these metals, and the problems of their weldability with stainless steel result in the use of more available and relatively low-cost materials such as $\mathrm{Cu}, \mathrm{Ni}$, and their alloys [12]. These interlayers have been used to prevent the formation of Ti-Fe IMCs during welding [10]. The mechanical resistance of such welds can be enhanced by adding an intermediate metal foil that modifies their final phase composition [1].

Among the metals mentioned above, $\mathrm{Cu}$ potentially would be a good choice to meet the needs of industry. $\mathrm{Cu}$ is compatible with $\mathrm{Fe}$ and does not produce brittle IMCs with $\mathrm{Fe}, \mathrm{Cr}, \mathrm{Ni}$, or $\mathrm{C}$. The $\mathrm{Cu}$ interlayer improves the metallurgical reaction of the weld pool, which leads to the formation of $\mathrm{Ti}-\mathrm{Cu}$ IMCs by reducing the proportion of $\mathrm{FeTi}$ and $\mathrm{Fe}_{2} \mathrm{Ti}$ IM phases. The formation of $\mathrm{Ti}_{\mathrm{x}} \mathrm{Cu}_{\mathrm{y}}$ phases is compensated by the high ductility and toughness of $\mathrm{Cu}$, which leads to acceptable strength. Additionally, the IMCs phases produced with $\mathrm{Cu}$ are tougher and have a lower hardness than the $\mathrm{Fe}-\mathrm{Ti}$ IMCs $[8,14,15]$. Moreover, $\mathrm{Cu}$ is a soft metal which may deform easily to reduce inner stress concentrations during laser welding and relax the residual stresses produced by linear expansion mismatch [16]. The properties of $\mathrm{Fe}-\mathrm{Cu}-\mathrm{Ti}$ systems indicate that the temperature stability of the joint is far inferior to that of steels and titanium alloys, due to the low-temperature transformations between $\mathrm{Cu}$-containing phases [1]

The direct bimetallic joining of austenitic 304 stainless steel and Ti6Al4V has been performed through diffusion bonding [17-20], brazing [21], explosive bonding [22], and roll bonding [23], as well as electron beam welding [7, 24]. Fusion welding is confronted with a great challenge in joining Ti alloys to steel. In traditional arc welding, it is very hard to manage the molten pool of the Ti-SS mixture due to metallurgical incompatibilities, so a mass of IMCs is formed during such welding.

In diffusion bonding of Ti to SS, a great care is needed for surface preparation. Using huge sheets of Ti and SS for this process is impossible, because it requires applying the large stresses on the materials and high-volume production capacity. It would also require a huge heat treatment system. Joint interfaces should have high standards of cleanliness, due to the long-term heat treating in a high-vacuum furnace $[1,3$, 25-27]. Friction stir welding presents a big challenge for the stir pin when the welding is performed on high-melting-point metals such as $\mathrm{Fe}$ and $\mathrm{Ti}$ alloys, especially during long-term usage of the stir pin $[3,27]$. Explosive welding has also been applied to join Ti and SS, but the process flexibility is very low when compared with the liquid state welding processes [26]. Brazing is not a good choice for high-temperature applications [27]. Ultrasonic welding is limited to apply on hard alloys such as Ti alloys [28].

Recently, the development of high-energy beam welding methods such as laser beam and electron beam welding has made fusion welding of Ti alloy to SS possible [9, 29]. Laser welding is used for the joining of dissimilar alloys because it provides a very localized heat supply, fast heating/cooling gradients, and high levels of precision in the weld [1]. Because of these advantages compared to other welding processes, laser welding is used for joining Ti alloy and SS using composite interlayers.

To achieve the maximum joint strength on Ti-SS welds, it is important to investigate the influence of changes in laser power as perhaps the most important parameter in the laser welding process on the strength of the joint. More specifically, the influence of laser power on the fracture surface characteristics of the weldments has not been investigated before.

Shanmugarajan [2] indicated that high-power density laser welding will enable welding at high speeds with a cooling rate of more than $1000{ }^{\circ} \mathrm{C} / \mathrm{s}$, creating favorable conditions in dissimilar materials joining through a reduction in the number and sizes of intermetallic phases in the fusion zone. The present work examines heretofore-uninvestigated influences of laser power on the phase characterization of the Ti-side of MZ through energy-dispersive spectroscopy (EDS) and Xray diffraction (XRD). Using these techniques, we not only correlate the influence of laser power on the joint strength but also on the phases occurred on the Ti-side of MZ.

\section{Experimental procedure}

The materials used in this study were 2-mm-thick plates of AISI 304 stainless steel, $\alpha-\beta$ Ti6Al4V alloy, and 1-mm-thick intermediate layer of pure copper. The size of the sheets used 
Table 1 Chemical composition of welded materials

Fig. 1 Schematic drawing of tensile test specimen (dimensions in $\mathrm{mm}$ )

\begin{tabular}{llllllllll}
\hline Material & \multicolumn{9}{l}{ Chemical composition (at.\%) } \\
\cline { 2 - 10 } & $\mathrm{Al}$ & $\mathrm{Ti}$ & $\mathrm{V}$ & $\mathrm{Cr}$ & $\mathrm{Fe}$ & $\mathrm{Ni}$ & $\mathrm{Cu}$ & $\mathrm{Mn}$ & $\mathrm{Si}$ \\
\hline AISI 304 & - & - & - & 18.28 & 70.15 & 8.05 & - & bal. & - \\
Ti6Al4V & 8.8 & 87.6 & 3.6 & - & - & - & - & - & - \\
Pure copper & - & - & - & - & - & - & 99.9 & - & - \\
\hline
\end{tabular}

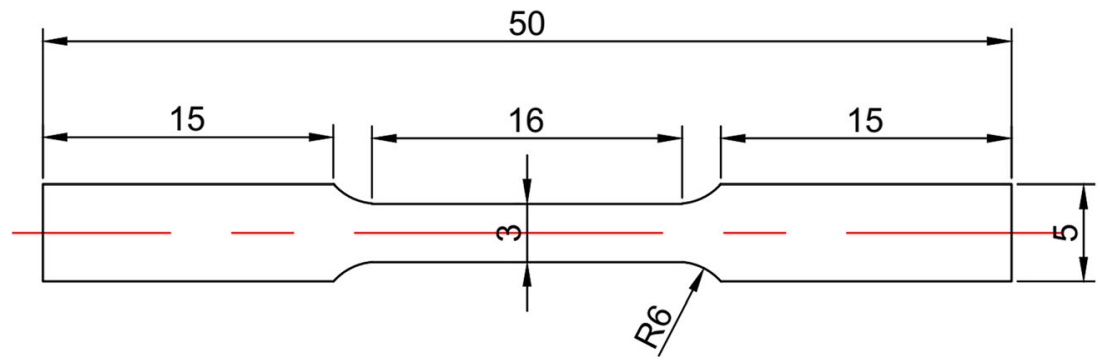

(a)
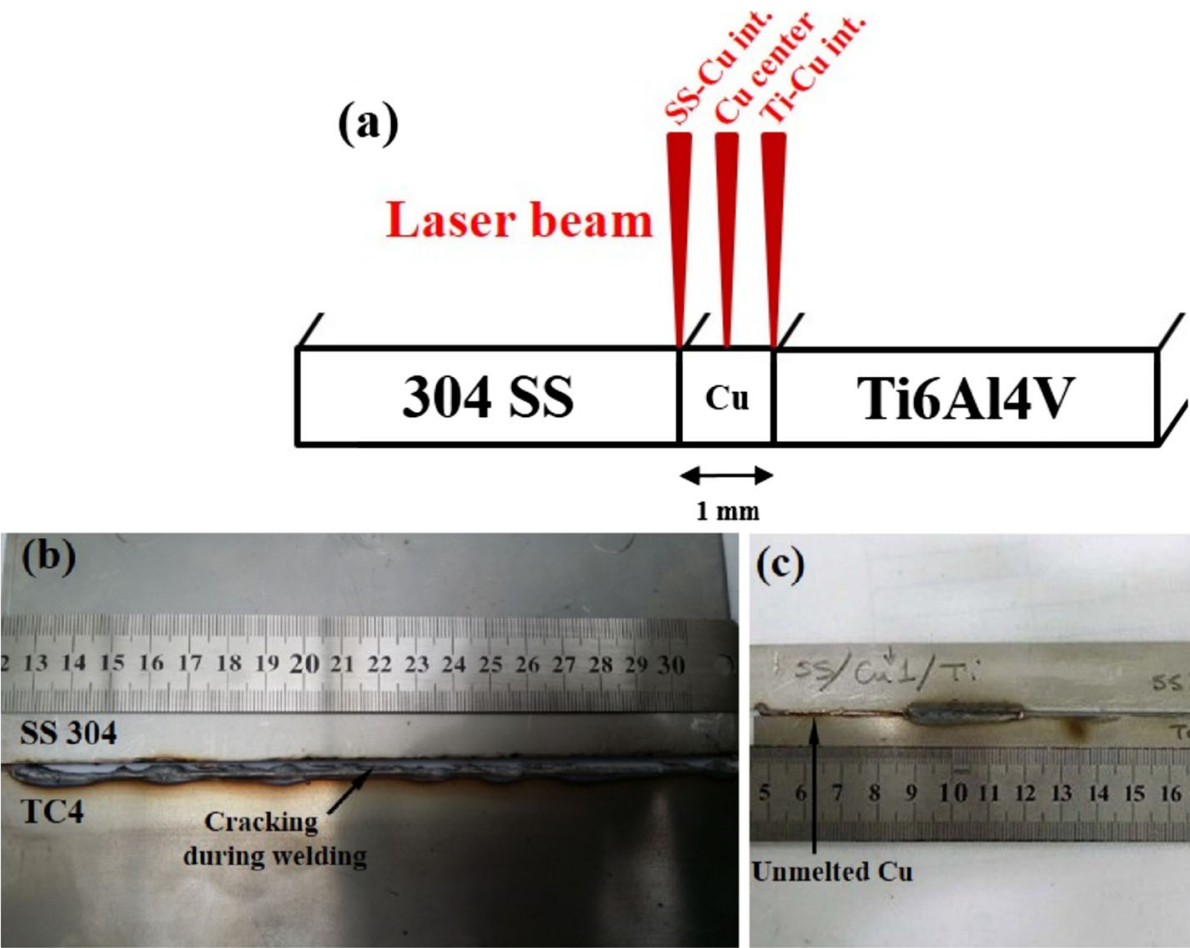

(c)

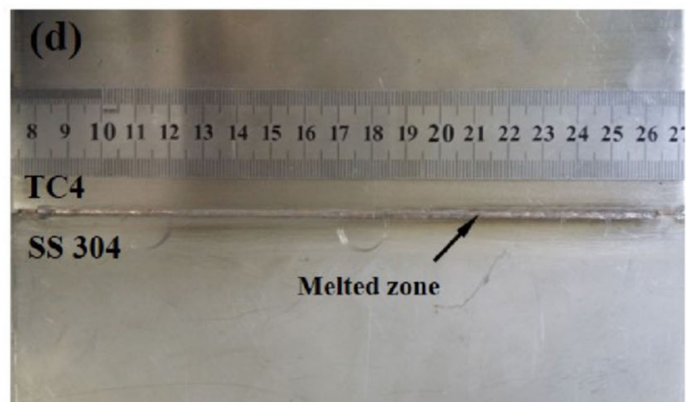

Fig. 2 a The schematic of laser welding setup with different focal positions, and the surface morphology of the joints welded with a Cu interlayer at a speed of $2 \mathrm{~m} / \mathrm{min}$ and a power of $3 \mathrm{~kW}$; the laser was focused on $\mathbf{b}$ the $\mathrm{Cu}$-Ti interface, $\mathbf{c}$ the $\mathrm{Cu}$ center, and $\mathbf{d}$ the $\mathrm{Cu}-\mathrm{SS}$ interface 
Fig. 3 a Stress-strain curves of pure Ti6A14V and 304 SS base metal sheets, and the fracture surface morphologies of pure $\mathbf{b}$ titanium alloy and $\mathbf{c}$ stainless steel after tensile testing

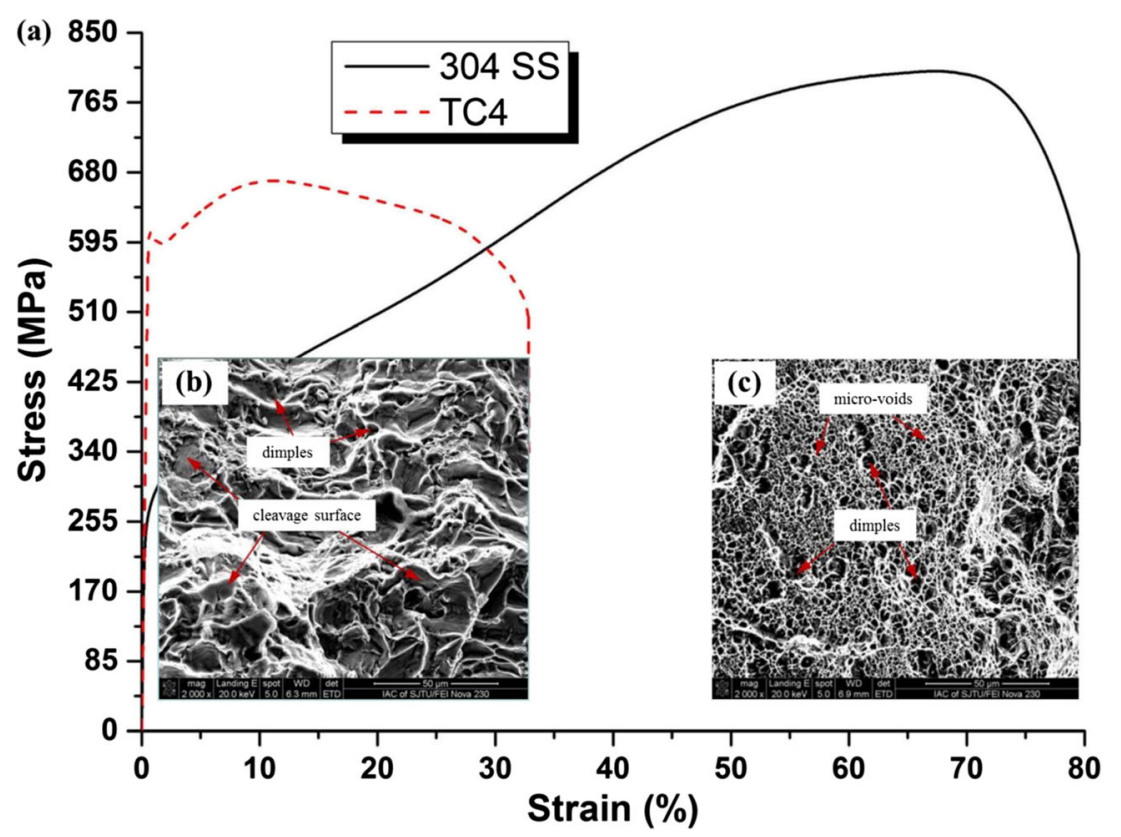

was $200 \times 100 \times 2 \mathrm{~mm}^{3}$. Their chemical compositions are listed in Table 1.

A high-power $(10 \mathrm{~kW})$ fiber laser welding machine (IPG 10000) with a wavelength of $1070 \mathrm{~nm}$, a welding-head focal distance of $300 \mathrm{~mm}$, and a focal beam diameter of $0.6 \mathrm{~mm}$ were used to convey the laser beam onto the specimens. First, the sheets were polished using a rough emery sheet to ensure the joining surfaces were smooth. Next, the joining surfaces were cleaned using acetone to remove dirt, oil, grease, and all other foreign materials, as was the $\mathrm{Cu}$. The $\mathrm{Cu}$ interlayer was then fixed to the edge of the SS plate by laser pulses on both sides of the joint. The Ti6Al4V and steel plates were then pressed together in butt configuration and maintained by mechanical fixation to avoid misalignment due to thermal expansion in a butt-weld geometry. The processing optical system was arranged at a $5^{\circ}$ inclination from the vertical to avoid

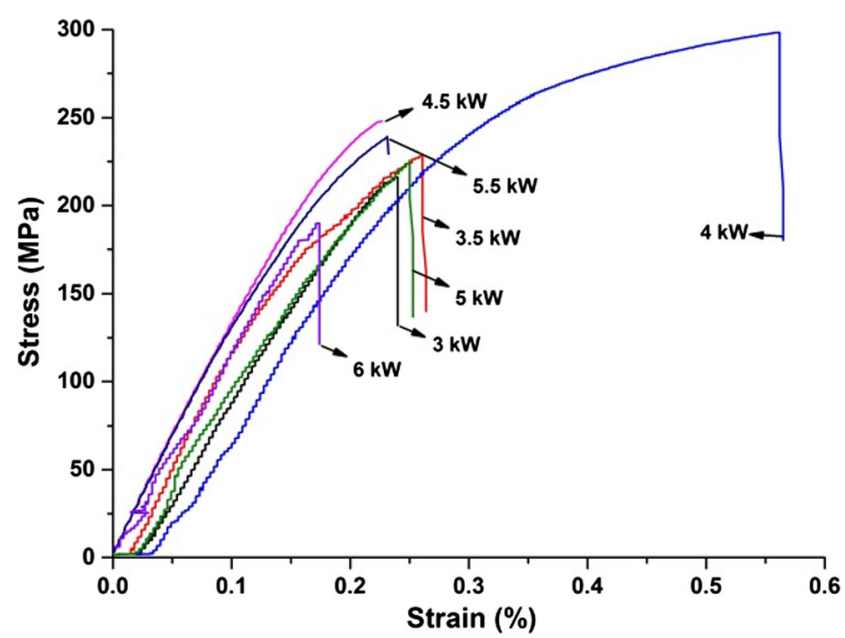

Fig. 4 The stress-strain curves of joints welded at different laser powers damage to fiber ends due to reflected light. A supplementary gas protection device covering the top and the bottom of the melted zone was used to minimize the risk of oxidation and plasma suppression that can lead to joint brittleness. Argon was used as the shielding gas and the total flow was $20 \mathrm{~L} \cdot \mathrm{min}^{-1}$ at the top and $10 \mathrm{~L} \cdot \mathrm{min}^{-1}$ at bottom of the joint through an 8-mm-diameter coaxial nozzle. The top nozzle was placed with the inclination angle of approximately $45^{\circ}$ to the specimen surface and the distance of $10 \mathrm{~mm}$ from the scanning point. The laser beam was positioned at the $\mathrm{Cu}-\mathrm{SS}$ interface, $\mathrm{Ti}-\mathrm{Cu}$ interface, and also $\mathrm{Cu}$ centerline in different investigations to obtain the best laser scanning path for joining Ti6Al4V to 304 SS. Different scanning paths are shown in Fig. 2a. The welding speed chosen was $2 \mathrm{~m} / \mathrm{min}$.

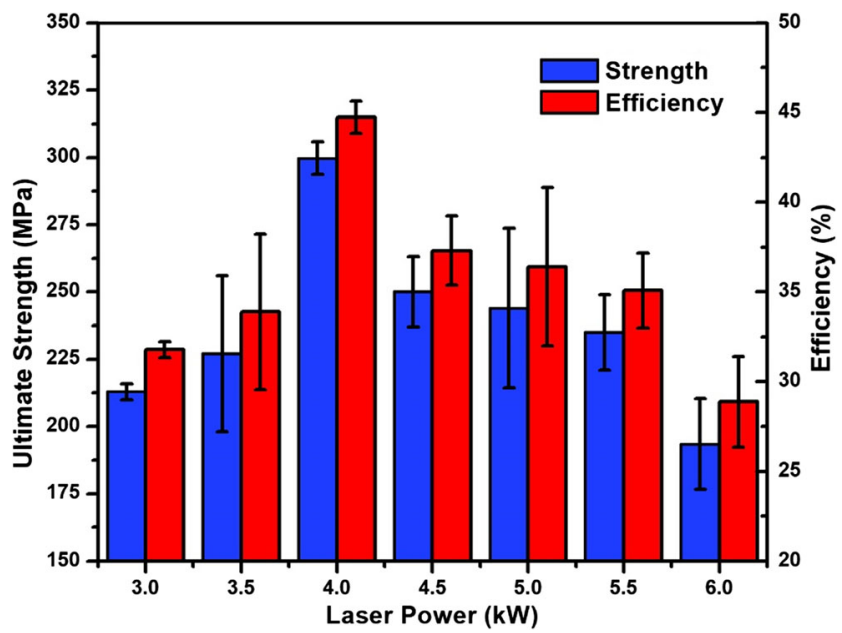

Fig. 5 The relationship between the ultimate strength and joint efficiency as affected by laser power 
Welded samples were sectioned, using wire electrical discharge machining, into small dog-bone samples for tensile testing, as well as cross-section analysis. Samples for crosssectional analysis were ground using carbide paper and then polished using alumina slurries. The samples for microstructural characterization were prepared metallographically and then were etched in a reagent of $20 \mathrm{~mL} \mathrm{HNO}_{3}, 20 \mathrm{~mL} \mathrm{HF}$, and $80 \mathrm{~mL} \mathrm{H}_{2} \mathrm{O}$ [30]. The analysis of microstructures of the samples was studied by scanning electron microscopes (NOVA NanoSEM 230, FEI, and Sirion 200, FEI) with fast EDS analyzers (Aztec $80 \mathrm{~mm}^{2}$ SDD, Oxford Instruments, and INCA X-act, Oxford Instruments). The precision of element analysis was to 1 at. $\%$.

The phases of the fracture surfaces were identified by XRD (SmartLab Ultima IV) using a $\mathrm{CuK}_{\alpha}$ radiation at an angle range $2 \theta$ from 30 to $90^{\circ}$ and at a scan speed of $1\left(^{\circ}\right) / \mathrm{min}$. The phases were identified according to the standard PDF card and Jade software.

To evaluate the tensile properties, the cross-weld tensile samples were prepared as the drawing in Fig. 1. To reduce surface roughness, all surfaces of the tensile specimens were polished by $400 \#$ abrasive papers. The tensile properties of the joints were measured by a universal testing machine (Zwick
Z100) operating at a constant tensile rate of $1 \mathrm{~mm} / \mathrm{min}$ at room temperature. The final tensile results reported were calculated from the mean of six samples from each weld. Vickers microindentation measurements were carried out using a 15s load time and a 100-mN load.

\section{Results and discussion}

\subsection{Laser weldability of the Ti/Cu/SS joint}

In order to evaluate the benefits of laser welding, investigations were undertaken to join 2-mm-thick Ti plates to similar thickness of $304 \mathrm{SS}$ with a $1-\mathrm{mm} \mathrm{Cu}$ interlayer. The joining was done following the identification of the best offset position via observation of the quality of the joint surface. Therefore, the welding experiments were first conducted according to three offset positions of laser focusing.

The schematic of the laser welding setup with different focal positions is shown in Fig. 2a. In this figure, three scanning paths that were considered for the laser radiation on the surface were the $\mathrm{Cu}-\mathrm{Ti}$ interface, $\mathrm{Cu}-\mathrm{SS}$ interface, and $\mathrm{Cu}$ (a)

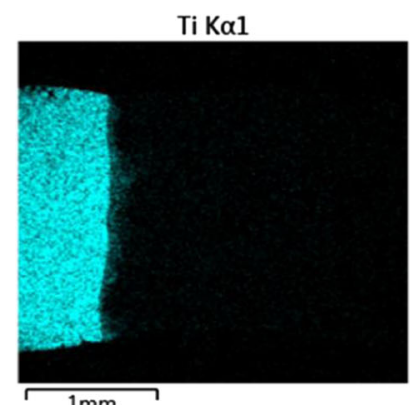

Ti $K \alpha 1$

(b)
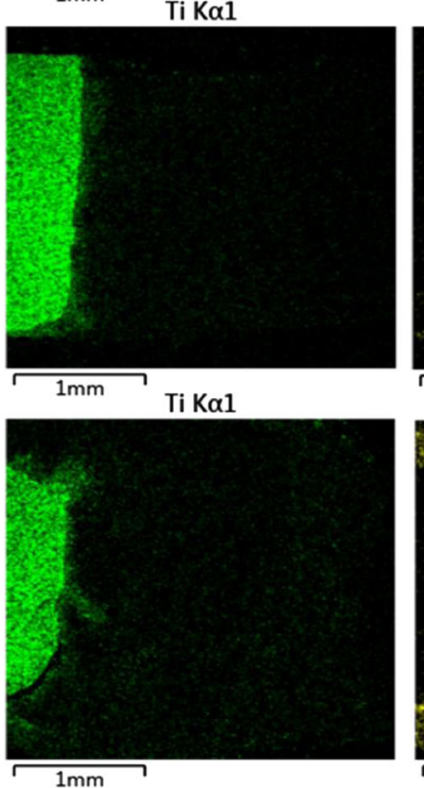

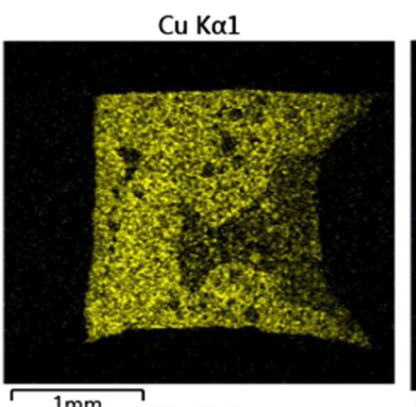

Cu K $\alpha 1$
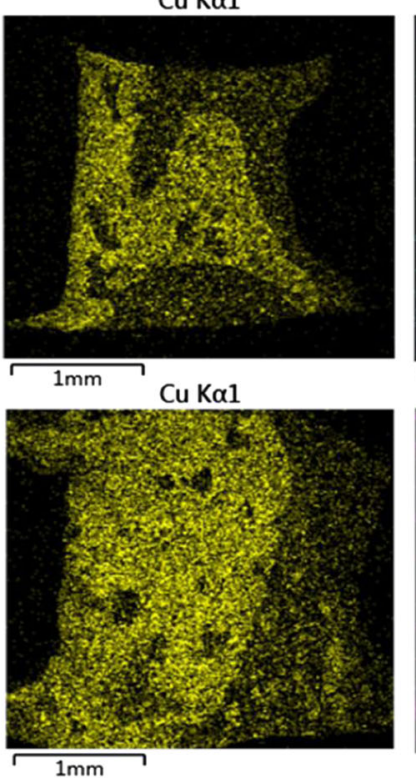
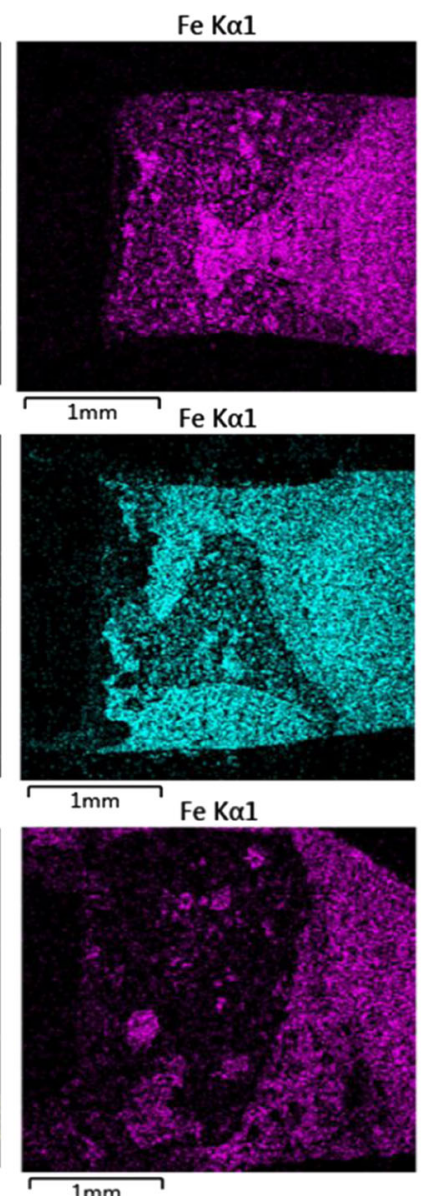
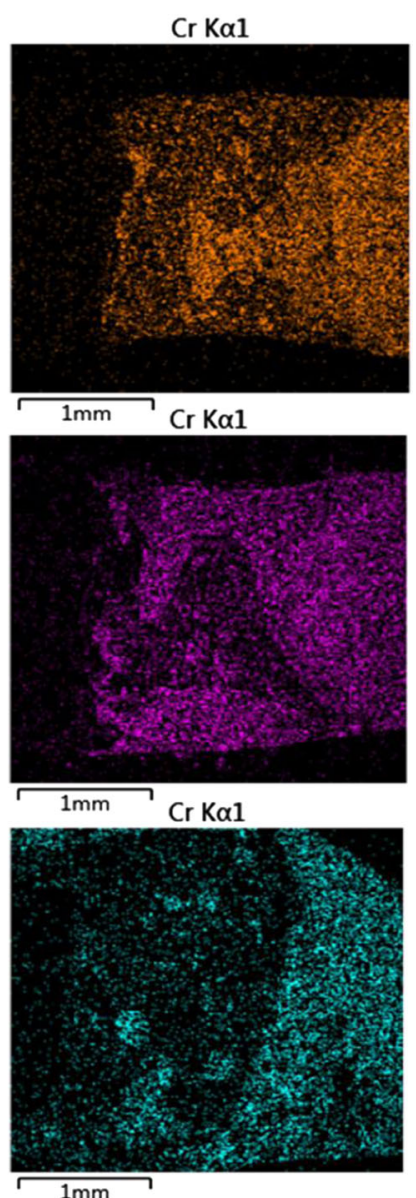

Fig. 6 X-ray distribution element maps in the welds obtained at laser powers of a $3 \mathrm{~kW}, \mathbf{b} 4 \mathrm{~kW}$, and $\mathbf{c} 6 \mathrm{~kW}$ 

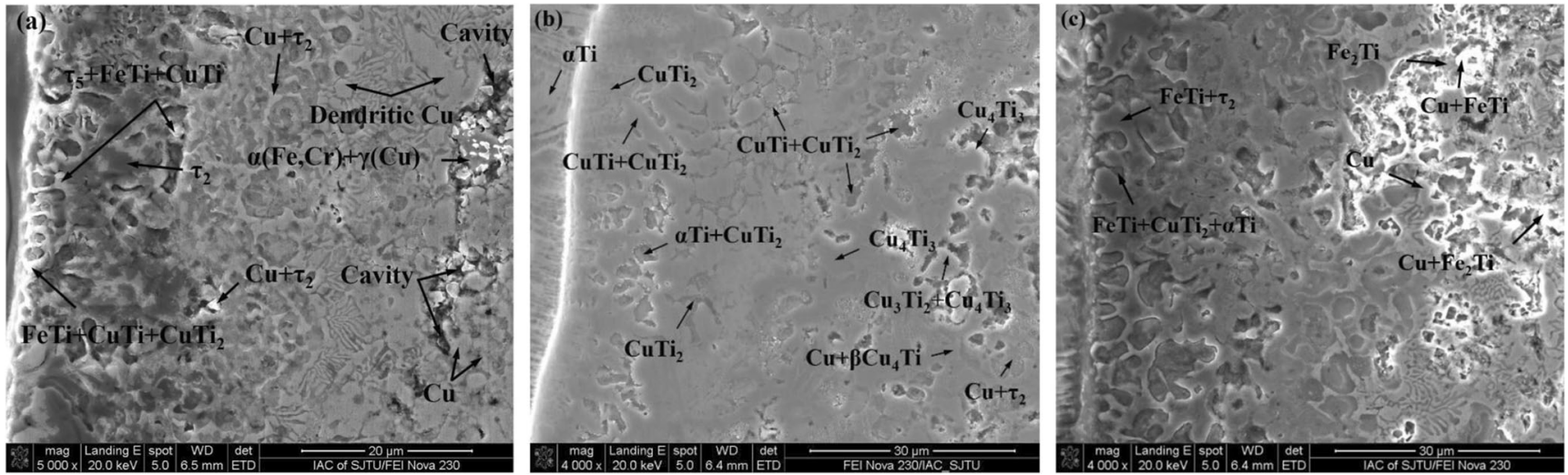

Fig. 7 The Ti-side microstructure of the MZ for samples welded at a $3 \mathrm{~kW}, \mathbf{b} 4 \mathrm{~kW}$, and $\mathbf{c} 6 \mathrm{~kW}$ laser power

centerline. Figure $2 \mathrm{~b}$ indicates that the shifting of laser beams at the $\mathrm{Cu}$-Ti interface caused an increase in participation of $\mathrm{Ti}$ atoms as the active element in the brittle intermetallics formation in the weld.
According to the Cu's low adsorption coefficient by the laser beam [31], the focal position on the centerline of the $\mathrm{Cu}$ interlayer was also not successful (as shown in Fig. 2c). As such, the best position for laser position was found to be

Table 2 Spot EDS analysis on the Ti-side of MZ for different laser-welded samples (at.\%)

\begin{tabular}{|c|c|c|c|c|c|c|c|c|c|c|c|}
\hline Power $(\mathrm{kW})$ & Phase POSITION & $\mathrm{Al}$ & $\mathrm{Ti}$ & V & $\mathrm{Cr}$ & $\mathrm{Mn}$ & $\mathrm{Fe}$ & $\mathrm{Ni}$ & $\mathrm{Cu}$ & Potential phase & Phase diagram \\
\hline \multirow[t]{11}{*}{3} & - & 0.00 & 49.66 & 0.27 & 1.46 & 0.25 & 9.98 & 1.11 & 37.26 & $\mathrm{FeTi}+\mathrm{CuTi}+\mathrm{CuTi}_{2}$ & \multirow[t]{6}{*}{$\mathrm{Fe}-\mathrm{Ti}-\mathrm{Cu}$} \\
\hline & - & 0.10 & 38.60 & 0.19 & 1.42 & 0.03 & 10.05 & 0.89 & 48.72 & $\tau_{2}$ & \\
\hline & Right & 0.05 & 46.66 & 0.10 & 0.90 & 0.09 & 3.39 & 0.73 & 48.08 & $\tau_{5}+\mathrm{FeTi}+\mathrm{CuTi}$ & \\
\hline & Left & 0.19 & 46.86 & 0.26 & 1.07 & 0.15 & 4.26 & 0.77 & 46.43 & $\tau_{5}+\mathrm{FeTi}+\mathrm{CuTi}$ & \\
\hline & Top & 0.24 & 17.69 & 0.00 & 0.76 & 0.40 & 3.91 & 0.86 & 76.12 & $\mathrm{Cu}+\tau_{2}$ & \\
\hline & Top, right & 0.21 & 27.85 & 0.02 & 1.11 & 0.11 & 5.48 & 1.10 & 64.11 & $\mathrm{Cu}$ & \\
\hline & Top, left & 0.20 & 7.85 & 0.02 & 0.25 & 0.35 & 1.51 & 0.41 & 89.41 & $\mathrm{Cu}$ & \multirow[t]{3}{*}{$\mathrm{Cu}-\mathrm{Fe}$ and $\mathrm{Ti}-\mathrm{Cu}$} \\
\hline & Bottom & 0.31 & 6.60 & 0.00 & 0.28 & 0.25 & 1.45 & 0.52 & 90.59 & $\mathrm{Cu}+\tau_{2}$ & \\
\hline & Bottom, right & 0.03 & 4.37 & 0.01 & 0.83 & 0.41 & 2.77 & 0.32 & 91.27 & $\mathrm{Cu}$ & \\
\hline & Bottom, left & 0.04 & 5.07 & 0.08 & 1.31 & 0.35 & 3.82 & 0.52 & 88.81 & $\mathrm{Cu}$ & $\mathrm{Fe}-\mathrm{Ti}-\mathrm{Cu}$ \\
\hline & - & 0.07 & 13.69 & 0.21 & 17.41 & 0.20 & 57.69 & 2.84 & 7.90 & $\alpha(\mathrm{Fe}, \mathrm{Cr})+\gamma(\mathrm{Cu})$ & $\mathrm{Cu}-\mathrm{Fe}-\mathrm{Cr}$ \\
\hline \multirow[t]{13}{*}{4} & - & 0.29 & 98.86 & 0.25 & 0.04 & 0.06 & 0.15 & 0.12 & 0.22 & $\alpha \mathrm{Ti}$ & \multirow[t]{12}{*}{$\mathrm{Ti}-\mathrm{Cu}$} \\
\hline & - & 0.17 & 53.13 & 0.30 & 2.52 & 0.34 & 13.44 & 1.44 & 28.65 & $\mathrm{CuTi}+\mathrm{CuTi}_{2}$ & \\
\hline & - & 0.24 & 69.09 & 0.08 & 2.25 & 0.31 & 6.89 & 1.10 & 20.03 & $\alpha \mathrm{Ti}+\mathrm{CuTi}_{2}$ & \\
\hline & Top & 0.17 & 63.15 & 0.12 & 0.50 & 0.11 & 1.33 & 0.77 & 33.86 & $\mathrm{CuTi}_{2}$ & \\
\hline & Bottom & 0.14 & 59.02 & 0.15 & 1.71 & 0.23 & 9.01 & 1.43 & 28.31 & $\mathrm{CuTi}_{2}$ & \\
\hline & Top, right & 0.09 & 60.46 & 0.10 & 1.20 & 0.18 & 4.64 & 1.07 & 32.26 & $\mathrm{CuTi}+\mathrm{CuTi}_{2}$ & \\
\hline & Top, left & 0.17 & 47.96 & 0.00 & 1.87 & 0.32 & 12.34 & 2.33 & 35.01 & $\mathrm{CuTi}+\mathrm{CuTi}_{2}$ & \\
\hline & Bottom & 0.13 & 47.92 & 0.07 & 1.93 & 0.43 & 11.90 & 2.33 & 35.29 & $\mathrm{CuTi}+\mathrm{CuTi}_{2}$ & \\
\hline & Top & 0.14 & 39.13 & 0.02 & 1.99 & 0.29 & 5.36 & 1.49 & 51.58 & $\mathrm{Cu}_{4} \mathrm{Ti}_{3}$ & \\
\hline & Bottom & 0.14 & 38.28 & 0.21 & 2.32 & 0.18 & 7.17 & 1.69 & 50.01 & $\mathrm{Cu}_{4} \mathrm{Ti}_{3}$ & \\
\hline & - & 0.21 & 35.41 & 0.06 & 2.10 & 0.46 & 8.23 & 1.68 & 51.84 & $\mathrm{Cu}_{3} \mathrm{Ti}_{2}+\mathrm{Cu}_{4} \mathrm{Ti}_{3}$ & \\
\hline & - & 0.26 & 12.40 & 0.00 & 0.17 & 0.57 & 1.08 & 0.44 & 85.09 & $\mathrm{Cu}+\beta \mathrm{Cu}_{4} \mathrm{Ti}$ & \\
\hline & - & 0.18 & 32.17 & 0.03 & 1.78 & 0.25 & 9.17 & 2.37 & 54.04 & $\mathrm{Cu}+\tau_{2}$ & $\mathrm{Fe}-\mathrm{Ti}-\mathrm{Cu}$ \\
\hline \multirow[t]{6}{*}{6} & - & 0.09 & 7.92 & 0.32 & 2.22 & 0.65 & 8.32 & 0.76 & 79.72 & $\mathrm{Cu}+\mathrm{Fe}_{2} \mathrm{Ti}$ & \multirow[t]{5}{*}{$\mathrm{Fe}-\mathrm{Ti}-\mathrm{Cu}$} \\
\hline & - & 0.00 & 10.66 & 0.44 & 4.21 & 0.67 & 13.14 & 1.75 & 69.13 & $\mathrm{Cu}+\mathrm{FeTi}$ & \\
\hline & - & 0.17 & 7.40 & 0.27 & 0.93 & 0.76 & 3.10 & 0.36 & 87.01 & $\mathrm{Cu}$ & \\
\hline & - & 0.00 & 62.38 & 1.59 & 2.15 & 0.42 & 7.74 & 1.09 & 24.62 & $\mathrm{FeTi}+\mathrm{CuTi}_{2}+\alpha \mathrm{Ti}$ & \\
\hline & - & 0.18 & 44.79 & 1.01 & 1.96 & 0.43 & 12.72 & 1.58 & 37.32 & $\mathrm{FeTi}+\tau_{2}$ & \\
\hline & - & 0.00 & 29.38 & 0.73 & 13.49 & 0.51 & 42.86 & 1.98 & 11.04 & $\mathrm{Fe}_{2} \mathrm{Ti}$ & $\mathrm{Fe}-\mathrm{Ti}-\mathrm{Cr}$ \\
\hline
\end{tabular}


the $\mathrm{Cu}$-SS interface which had been extended to the crack-free joint (Fig. 2d). The focusing of laser direction on the $\mathrm{Cu}-\mathrm{SS}$ interface, a high stainless steel enriched weld, can be formed from the $\mathrm{SS}$ side, due to the high solubility of $\mathrm{Cu}$ in iron, chromium, and nickel.

\subsection{Mechanical strength of the joints}

The stress-strain curves of pure 304 stainless steel and titanium alloy sheets are shown in Fig. 3. This figure shows that 304 SS has more strength and ductility than Ti6Al4V.

The fracture surface morphologies of both of these are shown in Figs. 3b, c after tensile testing. The pure SS fracture morphology depicts more ductile fracture modes, including dimples and micro-voids, while the Ti fracture surface includes a mixed mode of ductile and cleavage facets.

In order to investigate the effect of laser power on the mechanical strength of the joint, the welding process was performed at the powers of $3,3.5,4,4.5,5,5.5$, and $6 \mathrm{~kW}$ at the same welding speed of $2 \mathrm{~m} / \mathrm{min}$. When the laser power was lower than $3 \mathrm{~kW}$, no wetting of the melted zone happened on the Ti alloy. Meanwhile, the sound joints were not obtained at the laser powers settings higher than $6 \mathrm{~kW}$, according to the huge fluctuation of the elements in the melted zone. This was particularly true between $\mathrm{Ti}$ and $\mathrm{Fe}$ atoms, the presence of which caused more brittle IMCs to be formed in the weld.

The tensile curves of the joints welded with different powers are shown in Fig. 4. The curves show that the dissimilar joint welded at a power of $4 \mathrm{~kW}$ had the highest strength/ ductility value while that welded at $6 \mathrm{~kW}$ had the lowest of the samples tested.
The heat input of the laser welding process was calculated using the following expression:

H.I. $=\eta \frac{P}{S}$

where H.I. $=$ heat input, $P=$ laser power, $S=$ welding speed, and $\eta=$ welding efficiency for a laser welding process.

Joint efficiency was expressed as:

Joint Efficiency

$$
=\frac{\text { Strength of the joint }}{\text { Lower strength of the parent materials }} \%
$$

According to Fig. 3a, the ultimate strength of Ti6A14V and $304 \mathrm{SS}$ are 670 and $802 \mathrm{MPa}$, respectively.

The relationship between the ultimate strength and joint efficiency at various laser powers is depicted in Fig. 5. Figure 5 indicates that as the laser power increases toward $4 \mathrm{~kW}$, the strength, as well as the joint efficiency, increases. However, as laser power exceeds $4 \mathrm{~kW}$, the strength, as well as the joint efficiency, begin to decrease. The maximum strength and joint efficiency that can be reached at a laser power of $4 \mathrm{~kW}$ was up to $300 \mathrm{MPa}$ and $45 \%$, respectively (which is $35 \%$ more than the strength reported by Gao [6], when laser welding of the same pairing materials was previously investigated).

\subsection{Microstructure examination}

In order to investigate the influence of the incremental increase of laser power on the microstructural evolutions and

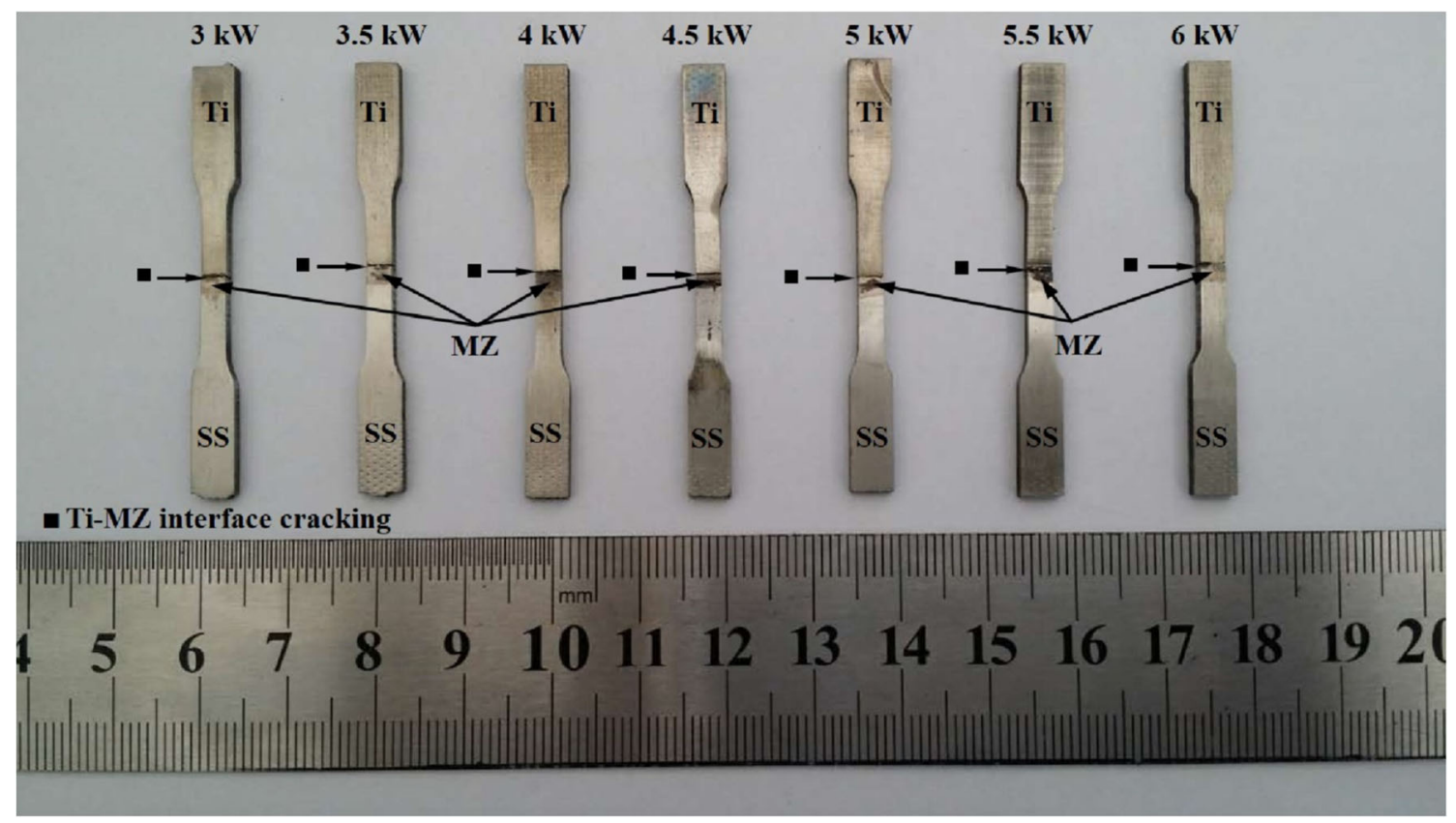

Fig. 8 The location of joint cracks at different laser powers after tensile testing 
the mechanical properties of the joints, samples welded at 3, 4, and $6 \mathrm{~kW}$ were chosen.

Figure 6 shows the major X-ray distribution element maps of the welds obtained at laser powers of 3,4 , and $6 \mathrm{~kW}$. As is visible in these figures, Ti and SS base metals were located on the left and right sides of the images, respectively. Figure 6 indicates that $\mathrm{Fe}$ and $\mathrm{Cr}$ atoms in all samples diffused simultaneously from the SS-side of the weld toward the center of it, after laser radiation on the SS-Cu interfaces. Meanwhile, the remainder of the MZs was occupied by copper. However, a few Ti atoms diffused from the Ti alloy toward the MZs.

$\mathrm{Ti}$ is an active element and tends to form IMCs with metal elements. Therefore, the Ti-side microstructures of melted zones were analyzed. The Ti-side microstructure of the melted zone (MZ) for the 3, 4, and $6 \mathrm{~kW}$ samples is shown in Fig. 7. This figure only shows the compounds that exist roughly $60 \mu \mathrm{m}$ from the Ti-side of the MZ. The chemical compositions of the Ti-side of the MZ from different laser-welded samples are shown in Table 2. The potential phases were extracted by combining the EDS results with Ti-Fe, Ti-Cu, Cu-Fe, Ti-Cr$\mathrm{Fe}, \mathrm{Cu}-\mathrm{Fe}-\mathrm{Cr}$, and Ti-Fe-Cu phase diagrams. "Phase Position" in Table 2 marks the positions with the same potential phases. Some brittle IMCs such as $\tau_{2}$, FeTi, $\tau_{5}, \mathrm{Fe}_{2} \mathrm{Ti}$, and $\mathrm{CuTi}$ as the most brittle phases of the Ti-Cu or Ti-Fe-Cu systems [13, 14] were formed at the Ti-side of the $\mathrm{MZ}$ at 3 and $6 \mathrm{~kW}$; however, no FeTi and $\mathrm{Fe}_{2} \mathrm{Ti}$ can be found in the 4-kW sample. Furthermore, minimum content of CuTi exists in the 4-kW sample. No defects were found at the Ti-side of melted zones.

Since the hardness of $\mathrm{FeTi} / \mathrm{Fe}_{2} \mathrm{Ti}$ compounds is much higher than other phases of the Fe-Ti-Cu system, the Ti-MZ interface in the 6 and $4 \mathrm{~kW}$ samples make for joints with the minimum and maximum strengths, respectively.

\subsection{Fractography}

Following the tensile experiment, the fracture side that includes the Ti6Al4V base metal is identified as the Ti-side, while the other which includes both 304 SS base metal and the $\mathrm{Cu}$ interlayer is identified as the SS-side. All of the welded samples joined at different laser powers were fractured at the Ti-side after tensile experiments (Fig. 8).

To investigate the fracture behavior of the weldment caused by increasing laser power, fractography of the samples welded at 3,4 , and $6 \mathrm{~kW}$ was performed on the Ti-side of fracture surfaces after tensile testing. The fracture morphologies are shown in Fig. 9.

Figure 9 shows that some secondary cracking can be observed on the fracture surfaces of all samples, due to the difference in the thermal expansion coefficient between Ti and SS that caused the cracking on the side of the weaker material. The close observation of the fracture surface of the 4-kW sample shows that most of the fracture surface area of this sample has a rough area which is characterized by the ductile-brittle fracture characteristics, containing obvious equiaxed dimple patterns and a few quasi-cleavages. This type of morphology means that the fracture behavior of this sample is more ductile than that of the samples laser welded at 3 or $6 \mathrm{~kW}$.

However, cleavage surfaces and river patterns were formed more on the fracture surfaces of the samples joined at 3 and $6 \mathrm{~kW}$. It is clear from the comparing of Figs. 9a, c that the tendency for surface cleavage in the sample that was welded at $6 \mathrm{~kW}$ was higher than that of the sample welded at $3 \mathrm{~kW}$.

In Fig. 9c, a relatively smooth area has been marked that was caused by a brittle rupture and some tearing ridges that are also evident from the river patterns. Consequently, it was found that the ratio of the rough area to the whole area on the fracture surface increased as the laser power increased, up to a power of $4 \mathrm{~kW}$; but this ratio decreased as the laser power rose above $4 \mathrm{~kW}$.

\subsection{Fracture analysis of the weld}

Figure 10 shows the X-ray diffraction analysis performed on the Ti-side fracture surfaces of the joints welded at different laser powers. Since many compounds were created at the fracture surfaces of the samples, the volume percent of each
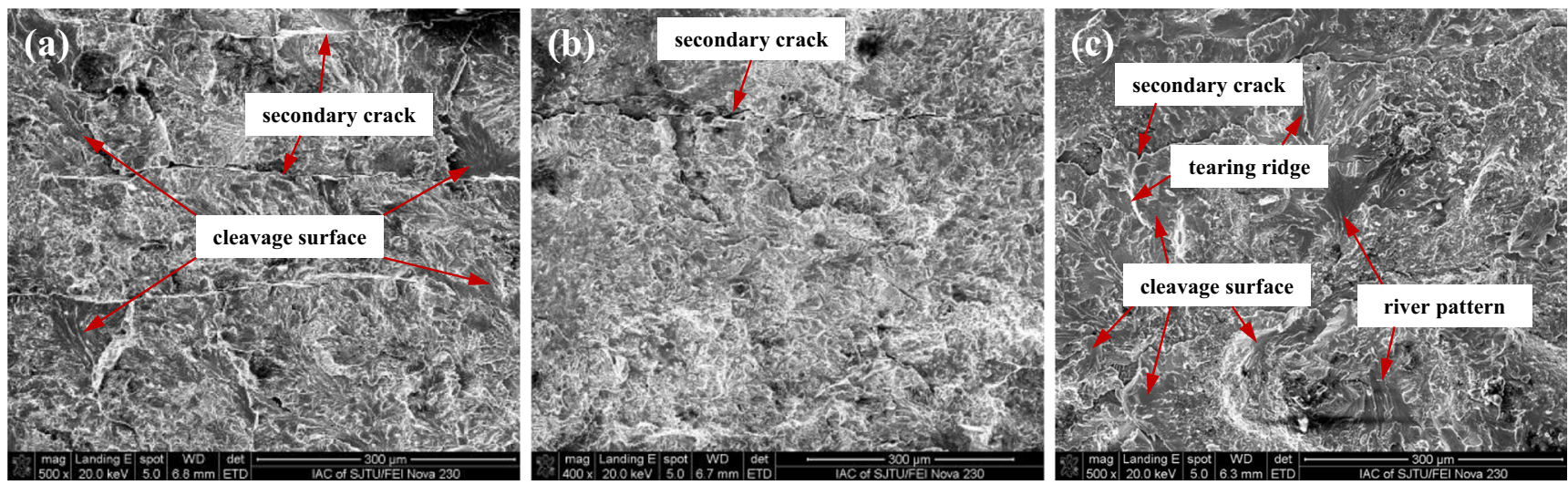

Fig. 9 The fracture surface morphology of the Ti-side of Ti-Cu-SS joints welded at the laser powers of a $3 \mathrm{~kW}, \mathbf{b} 4 \mathrm{~kW}$, and $\mathbf{c} 6 \mathrm{~kW}$ 

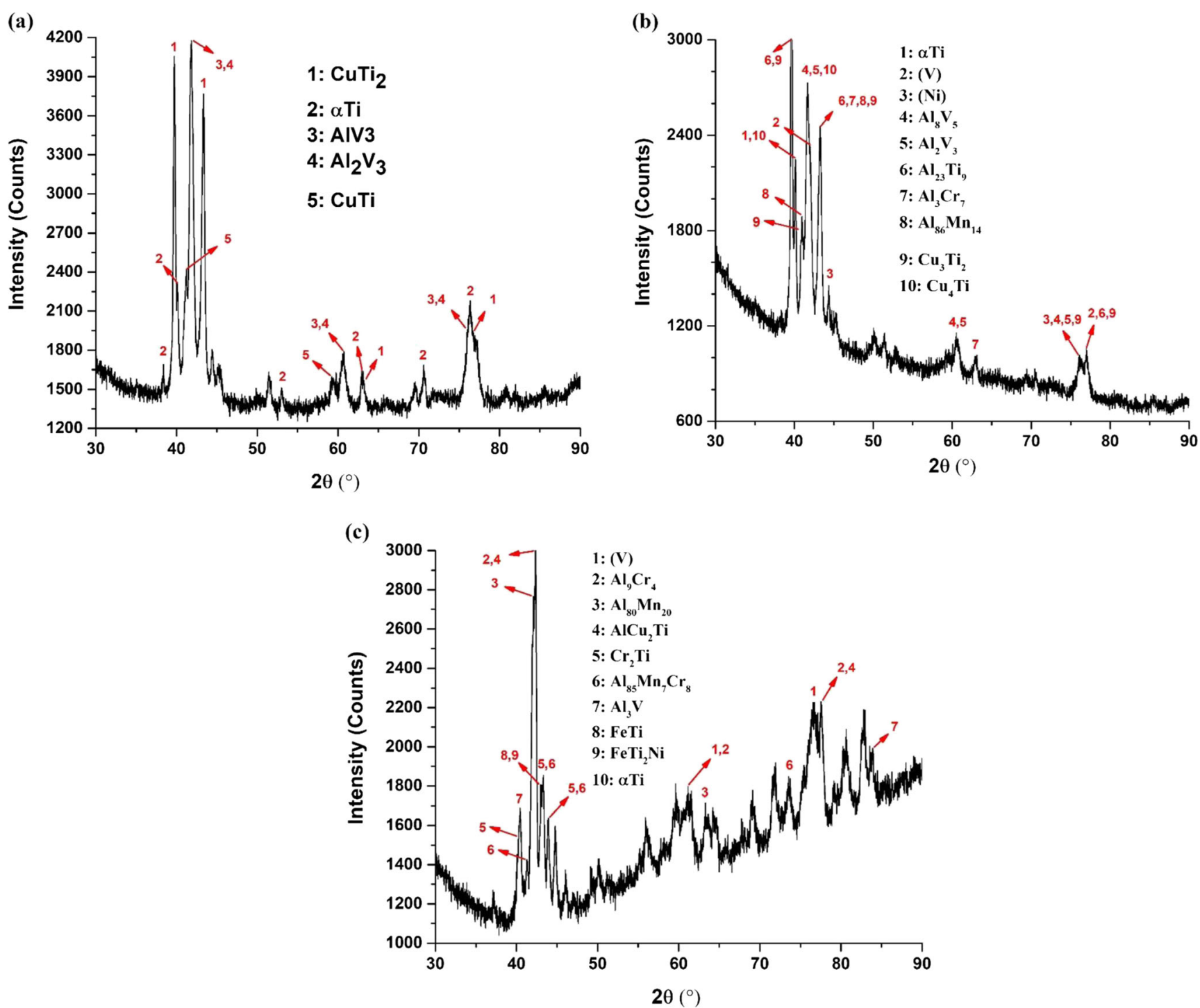

Fig. $10 \mathrm{X}$-ray diffraction analysis of the fracture surface of the joints welded at $\mathbf{a} 3 \mathrm{~kW}, \mathbf{b} 4 \mathrm{~kW}$, and $\mathbf{c} 6 \mathrm{~kW}$ laser powers

compound is low. Some solid solution phases, as well as some IMCs, formed in the fracture surface of welded samples. Figure 10 indicates that the only solid solution phase formed in all samples was $\alpha \mathrm{Ti}$, while the only solid solution compound formed at 4 and $6 \mathrm{~kW}$ was pure $(\mathrm{V})$. However, the fracture surface of the dissimilar Ti-Cu-SS pair welded at $4 \mathrm{~kW}$ not only contains $\alpha \mathrm{Ti}$ and $(\mathrm{V})$, but also some (Ni) solid solution compounds. All mentioned solid solutions formed in the fracture surfaces have a lower hardness than the IMCs $[8$, 9]. Meanwhile, $\mathrm{FeTi}$ and $\mathrm{Cr}_{2} \mathrm{Ti}$, recognized as the most brittle intermetallics, can be formed in the Ti-Cu-SS system [14]. Since the binary system of $\mathrm{Fe}-\mathrm{Cr}$ is mutually soluble in the solid state at high temperatures [9], the $\mathrm{Cr}$ atoms can replace the $\mathrm{Fe}$ atoms in the IMC lattice and then the $\mathrm{Fe}_{2} \mathrm{Ti}$ can be replaced with $\mathrm{Cr}_{2} \mathrm{Ti}$ in the $6-\mathrm{kW}$ sample. Therefore, it can be concluded that the brittleness of the $4-\mathrm{kW}$ welded sample was minimum, while it is at a maximum value for the $6-\mathrm{kW}$ laser power weldment.

There were some noises in some diffraction signals, due to the nature of the fracture surface. Therefore, less than three peaks were detected for some IMCs $[6,15]$.

The chemical compositions of the fracture surfaces of laserwelded samples are shown in Table 3. To perform accurate analysis on the fracture surfaces, both the cleavage and quasicleavage surfaces were examined by EDS. The EDS analysis was also performed on both the SS-side and Ti-side of the fracture surfaces.

The examination of the SS-side was only performed on the right-side of the fracture surface; the resultant phases are shown in Fig. 11. The Ti-side examination was performed on both the right-and-left-sides of the fracture surfaces, shown in Fig. 12. The potential phases were extracted by combining 
the EDS results with Ti-Fe, Ti-Cu, and Ti-Fe- $\mathrm{Cu}$ phase diagrams which are depicted in Fig. 13. The points in Figs. 11 and 12 that have the same potential phases are marked by numbers.

\subsection{Fracture mechanism}

In order to study the influence of laser power on the joint strength between the Ti and SS sheets, the copper content within the predominant phases was measured.

According to Figs. 11 and 12, the fracture surfaces in the 3 - and 4-kW samples are mainly composed of $\alpha \mathrm{Ti}+\mathrm{CuTi}_{2}$; however, in the $6-\mathrm{kW}$ sample, they are composed of $\alpha \mathrm{Ti}+\mathrm{FeTi}$. The analyzed points that exhibited the mentioned phases were 6 , 9, and 7 points for the samples welded at 3, 4, and $6 \mathrm{~kW}$, respectively. These points were counted from both the SS and Tisides, and from both the cleavage and the quasicleavage surfaces of the fracture surfaces. This means that the $\alpha \mathrm{Ti}+\mathrm{CuTi}_{2}$ and $\alpha \mathrm{Ti}+\mathrm{FeTi}$ eutectoid phases at the MZ-Ti6Al4V interface are the weakest zones within the joints welded at $3 \mathrm{~kW} / 4 \mathrm{~kW}$, and $6 \mathrm{~kW}$, respectively.

According to the phase diagram of Fig. 13c, the potential phases that were extracted were $\beta \mathrm{Ti}+\mathrm{Ti}_{2} \mathrm{Cu}$ and $\beta \mathrm{Ti}+\mathrm{FeTi}$. The XRD results from PDF cards indicated that the (Ti) phase has a space group of $\mathrm{P} 6_{3} / \mathrm{mmc}$ and lattice parameters of $a=2.950 \AA, b=2.950 \AA$, and $c=$ $4.683 \AA$, which is consistent with the results shown for $\alpha \mathrm{Ti}$ in reference [8].

Table 3 Spot EDS analysis on the fracture surface of laser-welded samples (at.\%)

\begin{tabular}{|c|c|c|c|c|c|c|c|c|c|c|c|c|c|}
\hline Power $(\mathrm{kW})$ & Side & Surface zone & No. & $\mathrm{Al}$ & $\mathrm{Ti}$ & V & $\mathrm{Cr}$ & $\mathrm{Mn}$ & $\mathrm{Fe}$ & $\mathrm{Ni}$ & $\mathrm{Cu}$ & Potential phase & Phase diagram \\
\hline \multirow[t]{9}{*}{3} & \multirow[t]{2}{*}{$\mathrm{SS}$} & \multirow[t]{2}{*}{ Right } & 2 & 8.14 & 60.98 & 0.04 & 0.74 & 0.20 & 4.88 & 0.91 & 24.12 & $\alpha \mathrm{Ti}+\mathrm{Ti}_{2} \mathrm{Cu}$ & $\mathrm{Ti}-\mathrm{Cu}$ \\
\hline & & & 1 & 0.28 & 64.16 & 0.33 & 1.49 & 0.17 & 6.39 & 1.08 & 26.77 & $\alpha \mathrm{Ti}+\mathrm{Ti}_{2} \mathrm{Cu}$ & $\mathrm{Ti}-\mathrm{Cu}$ \\
\hline & \multirow[t]{7}{*}{$\mathrm{Ti}$} & \multirow[t]{3}{*}{ Left } & & 0.39 & 54.76 & 0.39 & 1.79 & 0.13 & 9.57 & 1.17 & 32.58 & $\mathrm{TiCu}+\mathrm{Ti}_{2} \mathrm{Cu}$ & $\mathrm{Ti}-\mathrm{Cu}$ \\
\hline & & & 2 & 0.40 & 72.37 & 1.00 & 2.02 & 0.03 & 4.80 & 0.73 & 20.63 & $\alpha \mathrm{Ti}+\mathrm{Ti}_{2} \mathrm{Cu}$ & $\mathrm{Ti}-\mathrm{Cu}$ \\
\hline & & & 3 & 0.18 & 67.39 & 0.47 & 0.75 & 0.02 & 2.56 & 0.67 & 28.93 & $\alpha \mathrm{Ti}+\mathrm{Ti}_{2} \mathrm{Cu}$ & $\mathrm{Ti}-\mathrm{Cu}$ \\
\hline & & \multirow[t]{4}{*}{ Right } & & 0.55 & 55.14 & 0.26 & 1.95 & 0.07 & 9.96 & 1.01 & 31.60 & $\mathrm{TiCu}+\mathrm{Ti}_{2} \mathrm{Cu}$ & $\mathrm{Ti}-\mathrm{Cu}$ \\
\hline & & & & 1.74 & 3.81 & 0.11 & 0.33 & 0.82 & 91.78 & 0.09 & 1.54 & $\gamma \mathrm{Fe}$ & Ti-Fe \\
\hline & & & 2 & 0.14 & 64.72 & 0.34 & 1.18 & 0.07 & 5.19 & 0.96 & 28.20 & $\alpha \mathrm{Ti}+\mathrm{Ti}_{2} \mathrm{Cu}$ & $\mathrm{Ti}-\mathrm{Cu}$ \\
\hline & & & 1 & 0.37 & 66.77 & 0.87 & 1.04 & 0.07 & 4.28 & 0.85 & 27.49 & $\alpha \mathrm{Ti}+\mathrm{Ti}_{2} \mathrm{Cu}$ & $\mathrm{Ti}-\mathrm{Cu}$ \\
\hline \multirow[t]{10}{*}{4} & \multirow[t]{2}{*}{ SS } & \multirow[t]{2}{*}{ Right } & 1 & 0.12 & 65.81 & 0.51 & 1.01 & 0.03 & 4.41 & 0.81 & 28.32 & $\alpha \mathrm{Ti}+\mathrm{Ti}_{2} \mathrm{Cu}$ & $\mathrm{Ti}-\mathrm{Cu}$ \\
\hline & & & 2 & 0.32 & 66.96 & 0.34 & 1.03 & 0.04 & 3.71 & 0.92 & 27.35 & $\alpha \mathrm{Ti}+\mathrm{Ti}_{2} \mathrm{Cu}$ & $\mathrm{Ti}-\mathrm{Cu}$ \\
\hline & \multirow[t]{8}{*}{$\mathrm{Ti}$} & \multirow[t]{4}{*}{ Left } & 1 & 0.28 & 68.24 & 0.42 & 0.67 & 0.16 & 2.20 & 0.42 & 28.76 & $\alpha \mathrm{Ti}+\mathrm{Ti}_{2} \mathrm{Cu}$ & $\mathrm{Ti}-\mathrm{Cu}$ \\
\hline & & & 2 & 0.30 & 62.92 & 0.49 & 1.45 & 0.07 & 4.07 & 0.85 & 30.82 & $\alpha \mathrm{Ti}+\mathrm{Ti}_{2} \mathrm{Cu}$ & $\mathrm{Ti}-\mathrm{Cu}$ \\
\hline & & & 3 & 0.76 & 65.34 & 0.33 & 0.90 & 0.07 & 2.98 & 0.72 & 29.70 & $\alpha \mathrm{Ti}+\mathrm{Ti}_{2} \mathrm{Cu}$ & $\mathrm{Ti}-\mathrm{Cu}$ \\
\hline & & & & 0.26 & 52.29 & 0.44 & 2.14 & 0.05 & 13.93 & 1.28 & 30.48 & $\mathrm{TiCu}+\mathrm{Ti}_{2} \mathrm{Cu}$ & $\mathrm{Ti}-\mathrm{Cu}$ \\
\hline & & \multirow[t]{4}{*}{ Right } & 3 & 0.29 & 68.35 & 0.55 & 0.66 & 0.11 & 2.30 & 0.77 & 28.28 & $\alpha \mathrm{Ti}+\mathrm{Ti}_{2} \mathrm{Cu}$ & $\mathrm{Ti}-\mathrm{Cu}$ \\
\hline & & & 2 & 0.11 & 62.40 & 0.17 & 1.19 & 0.24 & 5.73 & 1.32 & 29.17 & $\alpha \mathrm{Ti}+\mathrm{Ti}_{2} \mathrm{Cu}$ & $\mathrm{Ti}-\mathrm{Cu}$ \\
\hline & & & 1 & 0.09 & 66.51 & 0.56 & 0.95 & 0.09 & 3.83 & 0.80 & 28.47 & $\alpha \mathrm{Ti}+\mathrm{Ti}_{2} \mathrm{Cu}$ & $\mathrm{Ti}-\mathrm{Cu}$ \\
\hline & & & 4 & 0.37 & 67.04 & 0.33 & 0.98 & 0.17 & 3.52 & 0.89 & 27.36 & $\alpha \mathrm{Ti}+\mathrm{Ti}_{2} \mathrm{Cu}$ & $\mathrm{Ti}-\mathrm{Cu}$ \\
\hline \multirow[t]{13}{*}{6} & \multirow[t]{3}{*}{$\mathrm{SS}$} & \multirow[t]{3}{*}{ Right } & 1 & 0.26 & 47.90 & 0.12 & 4.91 & 0.28 & 26.78 & 3.24 & 16.75 & $\mathrm{FeTi}+\alpha \mathrm{Ti}$ & $\mathrm{Ti}-\mathrm{Cu}-\mathrm{Fe}$ \\
\hline & & & 3 & 0.14 & 48.98 & 0.30 & 4.05 & 0.27 & 25.03 & 3.57 & 18.25 & $\mathrm{FeTi}+\alpha \mathrm{Ti}$ & $\mathrm{Ti}-\mathrm{Cu}-\mathrm{Fe}$ \\
\hline & & & & 0.30 & 29.85 & 0.17 & 13.99 & 0.36 & 47.94 & 3.16 & 4.23 & $\mathrm{FeTi}+\mathrm{Fe}_{2} \mathrm{Ti}$ & $\mathrm{Ti}-\mathrm{Fe}$ \\
\hline & \multirow[t]{10}{*}{$\mathrm{Ti}$} & \multirow[t]{5}{*}{ Left } & & 0.13 & 49.90 & 0.53 & 3.84 & 0.30 & 25.73 & 4.09 & 16.54 & FeTi+ $\alpha \mathrm{Ti}$ & $\mathrm{Ti}-\mathrm{Cu}-\mathrm{Fe}$ \\
\hline & & & 2 & 0.34 & 55.34 & 0.45 & 4.90 & 0.28 & 22.90 & 1.96 & 14.72 & $\mathrm{FeTi}+\alpha \mathrm{Ti}$ & $\mathrm{Ti}-\mathrm{Cu}-\mathrm{Fe}$ \\
\hline & & & & 0.09 & 46.75 & 0.28 & 2.52 & 0.32 & 7.89 & 2.04 & 40.68 & $\mathrm{TiCu}+\mathrm{Ti}_{2} \mathrm{Cu}$ & $\mathrm{Ti}-\mathrm{Cu}$ \\
\hline & & & 4 & 0.53 & 53.29 & 0.29 & 5.55 & 0.56 & 22.41 & 1.98 & 15.98 & $\mathrm{FeTi}+\alpha \mathrm{Ti}$ & $\mathrm{Ti}-\mathrm{Cu}-\mathrm{Fe}$ \\
\hline & & & & 0.38 & 40.03 & 0.08 & 8.32 & 0.28 & 37.05 & 4.38 & 9.65 & $\mathrm{FeTi}+\mathrm{Fe}_{2} \mathrm{Ti}+\mathrm{Cu}$ & $\mathrm{Ti}-\mathrm{Cu}-\mathrm{Fe}$ \\
\hline & & \multirow[t]{5}{*}{ Right } & 1 & 0.09 & 35.43 & 0.21 & 12.76 & 0.57 & 42.56 & 1.81 & 6.57 & $\mathrm{FeTi}+\mathrm{Fe}_{2} \mathrm{Ti}+\mathrm{Cu}$ & $\mathrm{Ti}-\mathrm{Cu}-\mathrm{Fe}$ \\
\hline & & & 2 & 0.03 & 50.30 & 0.23 & 4.73 & 0.37 & 25.07 & 2.27 & 17.46 & $\mathrm{FeTi}+\alpha \mathrm{Ti}$ & $\mathrm{Ti}-\mathrm{Cu}-\mathrm{Fe}$ \\
\hline & & & 3 & 0.44 & 25.03 & 0.18 & 10.44 & 0.55 & 39.78 & 4.24 & 19.70 & $\mathrm{FeTi}+\mathrm{Fe}_{2} \mathrm{Ti}+\mathrm{Cu}$ & $\mathrm{Ti}-\mathrm{Cu}-\mathrm{Fe}$ \\
\hline & & & 4 & 0.23 & 47.25 & 0.34 & 5.38 & 0.43 & 24.98 & 2.48 & 19.59 & $\mathrm{FeTi}+\alpha \mathrm{Ti}$ & $\mathrm{Ti}-\mathrm{Cu}-\mathrm{Fe}$ \\
\hline & & & & 0.10 & 21.56 & 0.04 & 0.88 & 0.98 & 2.49 & 0.51 & 73.44 & $\mathrm{Ti}_{2} \mathrm{Cu}_{3}+\beta \mathrm{TiCu}_{4}$ & $\mathrm{Ti}-\mathrm{Cu}$ \\
\hline
\end{tabular}




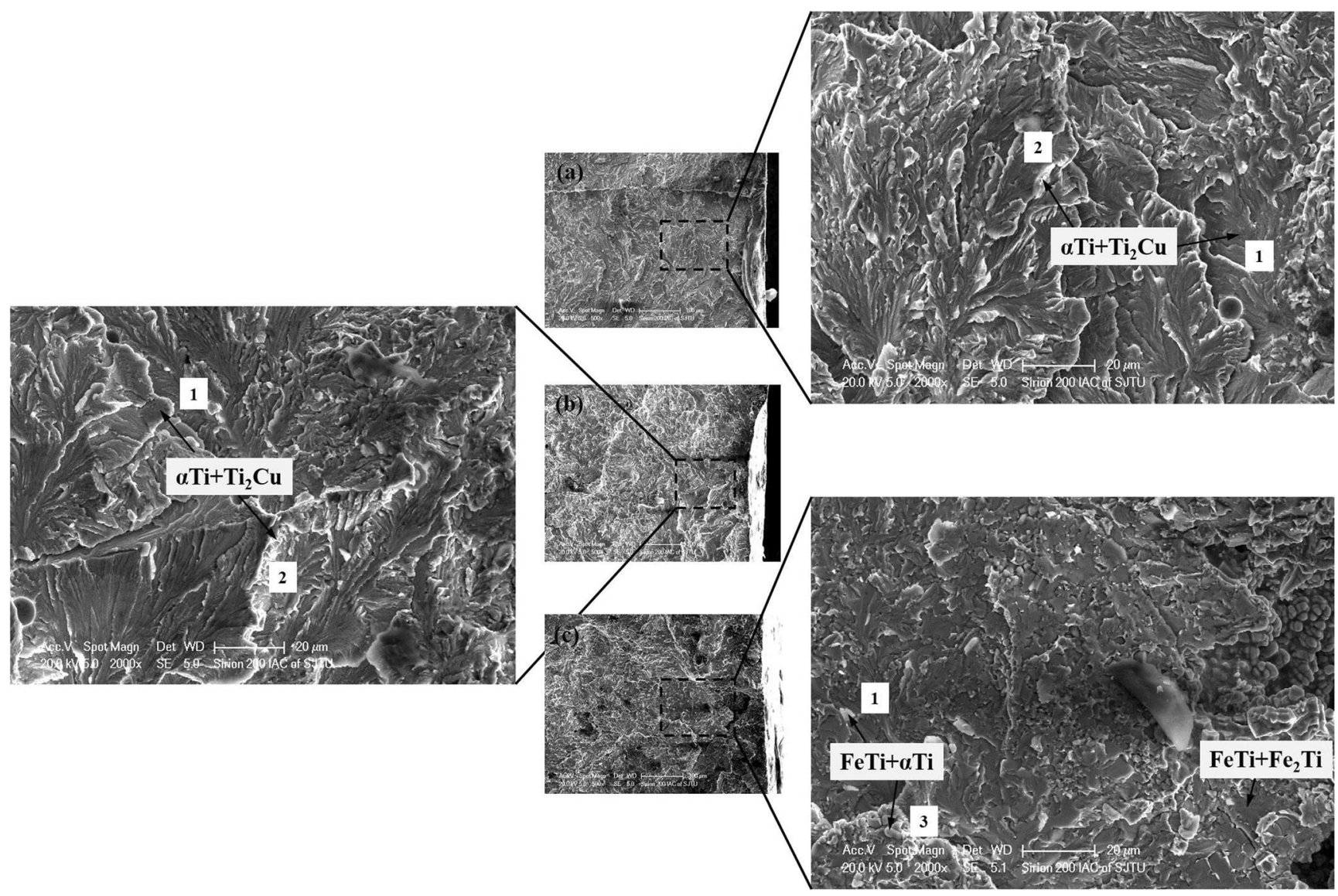

Fig. 11 The fracture surface analysis on the same regions of the SS-side of the joints welded at a $3 \mathrm{~kW}, \mathbf{b} 4 \mathrm{~kW}$, and $\mathbf{c} 6 \mathrm{~kW}$

According to Fig. 13b, the minimum equilibrium temperature for $\beta \mathrm{Ti} \rightarrow \alpha \mathrm{Ti}$ transformation is $\sim 800{ }^{\circ} \mathrm{C}$. This was a strong transformation and therefore $\alpha \mathrm{Ti}$ was produced due to the rapid cooling rate of the $\mathrm{MZ}$ during the laser welding process. The average $\mathrm{Cu}$ content within the $\alpha \mathrm{Ti}+\mathrm{Ti}_{2} \mathrm{Cu}$ and $\alpha \mathrm{Ti}+\mathrm{FeTi}$ phases that existed on the fracture surface of each sample was calculated. The relationship between the $\mathrm{Cu}$ content in the fracture surface of each joint and changes in laser power is shown in Fig. 14.

According to Fig. 14, a lower presence of $\mathrm{Cu}$ in the fracture surface indicates that the fracture surface primarily contains elements from Ti6Al4V. That is, the surface of the Ti6Al4V sheet contains some remaining $\mathrm{Cu}$ from the weld metal. Quantitative analysis and fracture characterization of the low $\mathrm{Cu}$ content fracture surface revealed that the crack occurred on the Ti surface. It can therefore be concluded that the low $\mathrm{Cu}$ content surfaces correspond to locations that lacked a sufficient interfacial layer; this kind of metallurgical joining leads to poor strength and joint failure. It therefore indicates that the fracture path passed close to the Ti alloy.

The sample welded at $6 \mathrm{~kW}$ had the lowest $\mathrm{Cu}$ content at the fracture surface, which means it had the lowest strength, as shown in Fig. 5.
Figure 14 also indicates that the $\alpha \mathrm{Ti}+\mathrm{Ti}_{2} \mathrm{Cu}$ phase was displaced by the $\alpha \mathrm{Ti}+\mathrm{FeTi}$ phase at the highest laser power. This is because at $6 \mathrm{~kW}$, the melt pool fluctuation increased, leading to the enhanced penetration of the Fe element toward the Ti alloy. Therefore, the Ti and Fe atoms met on the Ti-side of the MZ and formed FeTi.

The stability regions of the eutectoid phases, as circled in Fig. 13c, means that at the highest laser power the chemical composition of the $\mathrm{Ti}-\mathrm{Cu}$ interface changed from a $\alpha \mathrm{Ti}+$ $\mathrm{Ti}_{2} \mathrm{Cu}$ region to a $\alpha \mathrm{Ti}+\mathrm{FeTi}$ region. Since the hardness of FeTi is much higher than $\mathrm{Ti}_{2} \mathrm{Cu}$, the Ti-MZ interface in the $6-\mathrm{kW}$ sample is more brittle than those in the 3- and 4-kW samples.

Compared to those in the 3- or 6-kW samples, the increased presence of $\mathrm{Cu}$ atoms in the fracture surface of the $4-\mathrm{kW}$ sample was due to the $\mathrm{Cu}$ weld metal remaining more in the $\mathrm{Ti}$ alloy. Therefore, the fracture occurred much farther from the Ti surface than in samples with a lower level of $\mathrm{Cu}$. In the $4-\mathrm{kW}$ sample, $\mathrm{Cu}$ atoms could diffuse more inside the Ti surface and thus a stronger metallurgical joining could occur; this resulted in an increase up to $300 \mathrm{MPa}$ in the bond strength between Ti6Al4V and $\mathrm{Cu}$. This joint strength was higher 

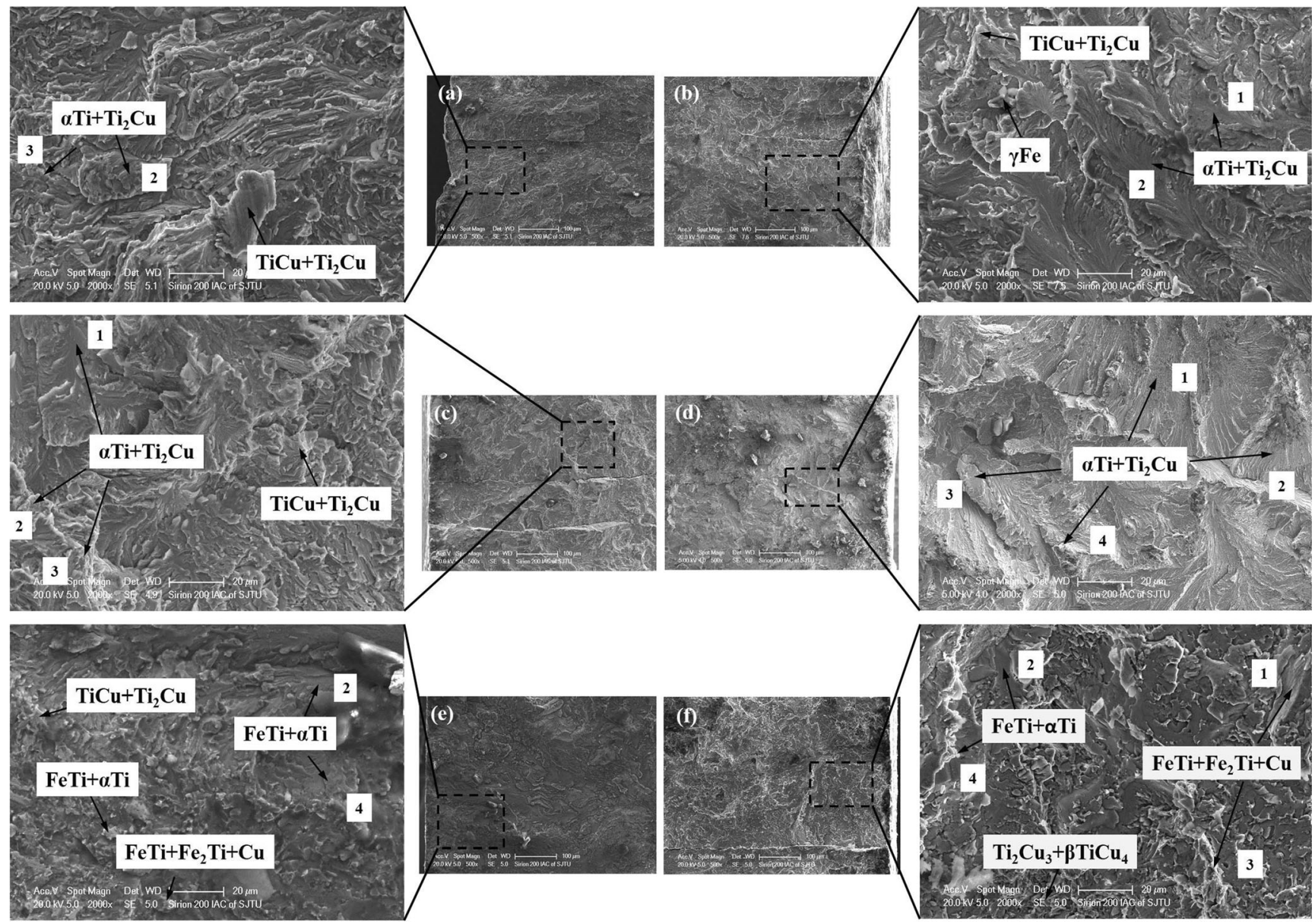

Fig. 12 The fracture surface analysis of the Ti-side of the fracture surfaces: left regions of the fracture surfaces of a $3 \mathrm{~kW}, \mathbf{c} 4 \mathrm{~kW}$, and e $6 \mathrm{~kW}$ samples; right regions of the fracture surfaces of $\mathbf{b} 3 \mathrm{~kW}, \mathbf{d} 4 \mathrm{~kW}$, and $\mathbf{f} 6 \mathrm{~kW}$ samples

than the strength of pure $\mathrm{Cu}$, which is $210 \mathrm{MPa}$. Consequently, the fracture path occurred toward the $\mathrm{Cu}$ interlayer.

Meanwhile, the Ti-MZ interface at the $6-$ and $4-\mathrm{kW}$ samples are the most brittle and ductile interfaces, due to the higher hardness of $\alpha \mathrm{Ti}+\mathrm{FeTi}$ compared with that of $\alpha \mathrm{Ti}+\mathrm{Ti}_{2} \mathrm{Cu}$. The schematic for the fraction paths in the $\mathrm{Ti}-\mathrm{Cu}$ interface at different laser powers is depicted in Fig. 15.

\section{Conclusion}

This paper is the first one to have investigated the fracture characteristics and strength of Ti6Al4V-304 SS joints welded at different laser powers. This has demonstrated that joint strength and the fracture paths of the weldments strongly depend on the degree of laser power. The joint strength increased as the laser power increased up to $4 \mathrm{~kW}$ and then decreased when the laser power exceeded $4 \mathrm{~kW}$. (a)

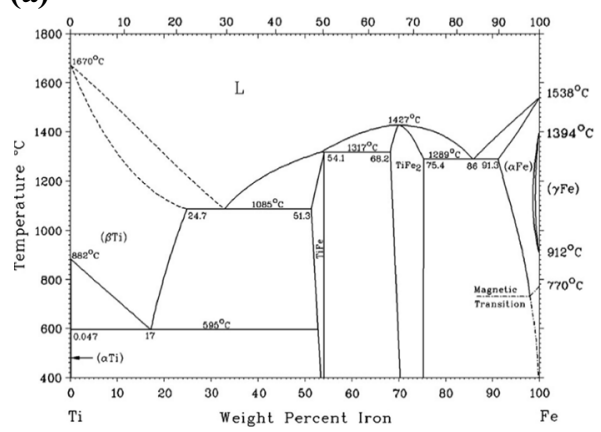

(b)

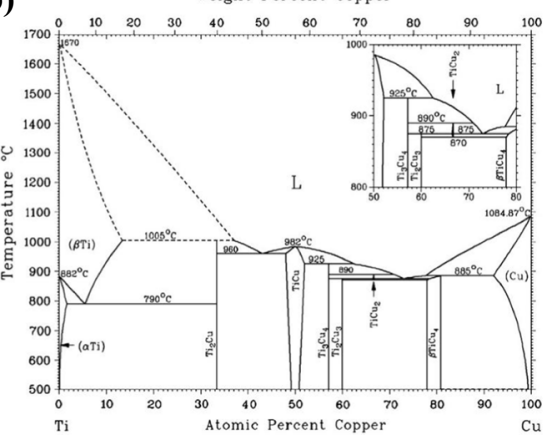

(c)

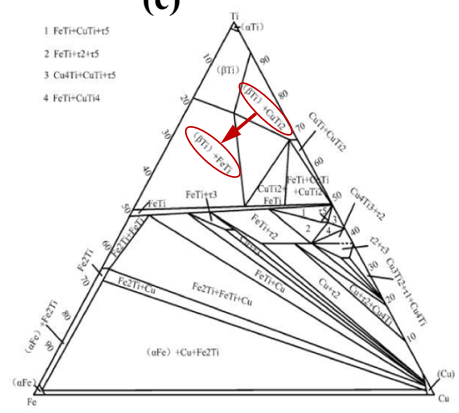

Fig. 13 a Ti-Fe, and $\mathbf{b}$ Ti-Cu binary phase diagrams, and $\mathbf{c}$ isothermal section of Ti-Fe-Cu phase diagram at $849^{\circ} \mathrm{C}$ 


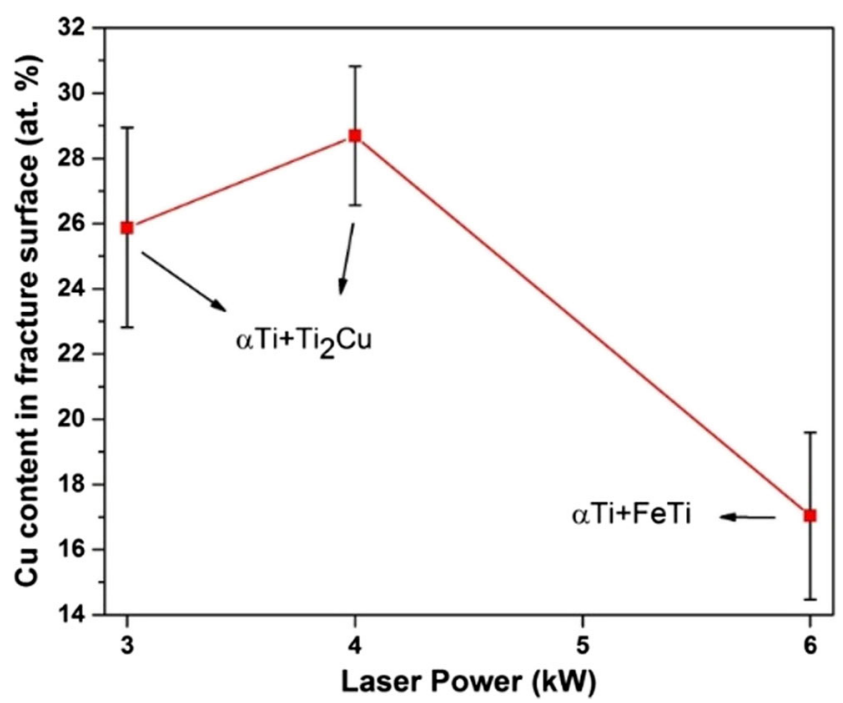

Fig. 14 The relationship between the $\mathrm{Cu}$ content in the fracture surface of weldments and laser power variation

As determined by fracture characterization of welded joints, the influence of various laser power settings during welding on the mechanical strength can be summarized as follows:

1. Maximum joint strength occurred when high values of $\mathrm{Cu}$ deposit remained on the fracture surface. Conversely, minimum strength was a result of low remaining $\mathrm{Cu}$ deposited on the fracture surface. The higher values of $\mathrm{Cu}$ on the fracture surface showed that $\mathrm{Cu}$ atoms diffused into the Ti surface to a greater extent, which allowed an optimal metallurgical joining to occur. This increased the strength between Ti6Al4V and $\mathrm{Cu}$ to a point beyond that of pure $\mathrm{Cu}$. Consequently, the fracture path happened toward the $\mathrm{Cu}$ interlayer. $\mathrm{A}$ low $\mathrm{Cu}$ content on the fracture surface occurred due to an insufficient interfacial layer between Ti6A14V and $\mathrm{Cu}$ and resulted in a metallurgical joining with a low strength and high failure characteristics. Therefore, the fracture path passed close to the Ti alloy.

2. The EDS characterizations of fracture surfaces showed that $\alpha \mathrm{Ti}+\mathrm{FeTi}$ was displaced from the $\alpha \mathrm{Ti}+\mathrm{Ti}_{2} \mathrm{Cu}$ phase at the highest laser power. According to the higher

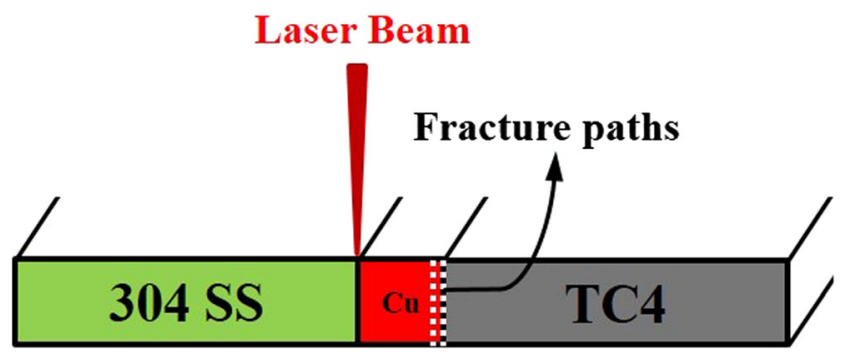

Fig. 15 Schematic of the fracture paths in the dissimilar Ti6Al4V-Cu-304 $\mathrm{SS}$ joint at different laser powers brittleness of $\mathrm{FeTi}$ relative to $\mathrm{Ti}_{2} \mathrm{Cu}$, the interface between Ti6Al4V and MZ in the 6-kW sample was more brittle than those of the samples welded at 3 and $4 \mathrm{~kW}$.

3. The ratio of the rough area to the whole area in the fracture surface increased as laser power increased up to $4 \mathrm{~kW}$. However, as laser power increases beyond $4 \mathrm{~kW}$, it then decreased. This means that the majority of the fracture surface of a 4-kW weldment had a rough area characterized by ductile-brittle fracture characteristics. The $4-\mathrm{kW}$ fracture surface contained obvious equiaxed dimple patterns and a small number of quasi-cleavages. It was also clear that the tendency for cleavage surface formation in the sample welded at $6 \mathrm{~kW}$ power was higher than that of the sample welded at $3 \mathrm{~kW}$.

4. There are visible peaks of various solid solutions: $\alpha \mathrm{Ti}$, $(\mathrm{V}),(\mathrm{Ni})$ coexisting with numerous kinds of Al-IMCs in the fracture surface of $4 \mathrm{~kW}$ weldment; however, the only solid solution phases formed in 3 and $6 \mathrm{~kW}$ samples are $\alpha \mathrm{Ti}$ and $(\mathrm{V})$, respectively. Due to the lower hardness of solid solutions when compared with the IMCs, the brittleness of a 4-kW laser-welded sample is lower than that of the 3 or $6 \mathrm{~kW}$ weldments.

Acknowledgements The authors gratefully acknowledge the financial support of the National Natural Science Foundation of China (Grant No. 51175338), the Green Manufacturing Industry Project from Ministry of Industry and Information Technology of China, and the Intelligent Manufacturing Industry Project from Lingang district of Shanghai Municipality. The authors also gratefully acknowledge Jiaxing Hong Bao Lu Metal Materials for providing titanium alloys. Meanwhile, the cooperation of Chao Zhang, Shuqiang Tian, Yanbing Guo, Wenjie Ren, and Zhiyuan Wang is appreciated. The authors also acknowledge analysis support by Z.Q. Bao of Instrumental Analysis Center at SJTU.

Open Access This article is distributed under the terms of the Creative Commons Attribution 4.0 International License (http:// creativecommons.org/licenses/by/4.0/), which permits unrestricted use, distribution, and reproduction in any medium, provided you give appropriate credit to the original author(s) and the source, provide a link to the Creative Commons license, and indicate if changes were made.

\section{References}

1. Tomashchuk I, Grevey D, Sallamand P (2015) Dissimilar laser welding of AISI 316L stainless steel to Ti6-A14-6V alloy via pure vanadium interlayer. Mater Sci Eng A 622:37-45

2. Shanmugarajan B, Padmanabham G (2012) Fusion welding studies using laser on Ti-SS dissimilar combination. Opt Lasers Eng 50: $1621-1627$

3. Gao M, Mei SW, Wang ZM, Li XY, Zeng XY (2012) Characterisation of laser welded dissimilar Ti/steel joint using $\mathrm{Mg}$ interlayer. Sci Technol Weld Join 17(4):269-276

4. Zhang Y, Sun DQ, Gu XY, Liu YJ (2017) Nd/YAG (2017) pulsed laser welding of TC4 titanium alloy to $301 \mathrm{~L}$ stainless steel via pure copper interlayer. Int J Adv Manuf Technol 90:953-961 
5. Hiraga H, Fukatsu K, Ogawa K, Nakayama M, Muto Y (2002) Nd: YAG laser welding of pure titanium to stainless steel. Weld Int 16(8):623-631

6. Gao M, Chen C, Wang L, Wang Z, Zeng X (2015) Laser-arc hybrid welding of dissimilar titanium alloy and stainless steel using copper wire. Metall Mater Trans A 46A:2007-2020

7. Sahasrabudhe H, Harrison R, Carpenter C, Bandyopadhyay A (2015) Stainless steel to titanium bimetallic structure using LENS $^{\text {TM }}$. Addit Manuf 5:1-8

8. Tomashchuk I, Sallamand P, Belyavina N, Pilloz M (2013) Evolution of microstructures and mechanical properties during dissimilar electron beam welding of titanium alloy to stainless steel via copper interlayer. Mater Sci Eng A 585:114-122

9. Chen S, Zhang M, Huang J, Cui C, Zhang H, Zhao X (2014) Microstructures and mechanical property of laser butt welding of titanium alloy to stainless steel. Mater Des 53:504-511

10. Wang T, Zhang B, Chen G, Feng J (2013) High strength electron beam welded titanium-stainless steel joint with $\mathrm{V} / \mathrm{Cu}$ based composite filler metals. Vacuum 94:41-47

11. Mohid Z (2014) Dissimilar materials laser welding characteristics of stainless steel and titanium alloy. Appl Mech Mater 465-466: 1060-1064

12. He P, Zhang J, Zhou R, Li X (1999) Diffusion bonding technology of a titanium alloy to a stainless steel web with an $\mathrm{Ni}$ interlayer. Mater Charact 43:287-292

13. Balasubramanian M (2015) Application of Box-Behnken design for fabrication of titanium alloy and 304 stainless steel joints with silver interlayer by diffusion bonding. Mater Des 77:161-169

14. Pardal G, Ganguly S, Williams S, Vaja J (2016) Dissimilar metal joining of stainless steel and titanium using copper as transition metal. Int J Adv Manuf Technol 86(Issue 5):1139-1150

15. Zhang B, Wang T, Chen G, Feng J (2012) Contact reactive joining of TA15 and 304 stainless steel via a copper interlayer heated by electron beam with a beam deflection. JMEPEG 21:2067-2073

16. Wang T, Zhang B, Feng J (2014) Influences of different filler metals on electron beam welding of titanium alloy to stainless steel. Trans Nonferrous Met Soc China 24:108-114

17. Zhao DS, Yan JC, Liu YJ, Ji ZS (2014) Interfacial structure and mechanical properties of hot-roll bonded joints between titanium alloy and stainless steel using niobium interlayer. Trans Nonferrous Met Soc China 24:2839-2844
18. He P, Yue X, Zhang JH (2008) Hot pressing diffusion bonding of a titanium alloy to a stainless steel with an aluminum alloy interlayer. Mater Sci Eng A 486:171-176

19. Ghosh M, Samar D, Banarjee PS, Chatterjee S (2005) Variation in the reaction zone and its effects on the strength of diffusion bonded titanium-stainless steel couple. Mater Sci Eng A 390:217-226

20. Ghosh M, Chatterjee S, Mishra B (2003) The effect of intermetallics on the strength properties of diffusion bonds formed between Ti-5.5Al-2.4V and 304 stainless steel. Mater Sci Eng A 363:268274

21. Yue X, He P, Feng JC, Zhang JH, Zhu FQ (2008) Microstructure and interfacial reactions of vacuum brazing titanium alloy to stainless steel using an AgCuTi filler metal. Mater Charact 59:17211727

22. Kahraman N, Gulenc B, Findik F (2005) Joining of titanium/ stainless steel by explosive welding and effect on interface. $\mathrm{J}$ Mater Process Technol 169:127-133

23. Yan JC, Zhao DS, Wang CW, Wang LY, Wang Y, Yang SQ (2009) Vacuum hot roll bonding of titanium alloy and stainless steel using nickel interlayer. Mater Sci Technol 25(7):914-918

24. Barin I (1995) Thermochemical data of pure substances, 3rd edn. WILEY-VCH Velag GmbH, Germany

25. Liu C (2007) Characterisation and modelling of Interface reactions between diamond and active brazing alloys. Diss ETH No 17469

26. Manikandan P, Hokamoto K, Fujita M, Raghukandan K, Tomoshige R (2008) Control of energetic conditions by employing interlayer of different thickness for explosive welding of titanium/ 304 stainless steel. J Mater Process Technol 195:232-240

27. Wang T, Zhang BG, Chen GQ, Feng JC, Tang Q (2010) Electron beam welding of Ti-15-3 titanium alloy to 304 stainless steel with copper interlayer sheet. Trans Nonferrous Met Soc China 20:1829-1834

28. Satoh G, Yao YL, Qiu C (2013) Strength and microstructure of laser fusion-welded Ti-SS dissimilar material pair. Int J Adv Manuf Technol 66:469-479

29. Kutsuna M, Ichioka R (2007) Dissimilar metal joining of steel and titanium by laser roll welding. Weld World 51:5-8

30. Ting W, Binggang Z, Jicai F, Qi T (2012) Effect of a copper filler metal on the microstructure and mechanical properties of electron beam welded titanium-stainless steel joint. Mater Charact 73:104-113

31. Groza C, Mitelea I, Craciunescu C (2012) Melted zone morphology by laser welding of Ti-6AL-4V with X5CRNI18-10. Brno Czech Republic, EU 23-25 